\title{
FIGHT CORRUPTION AT THE STATE AND MUNICIPAL LEVELS IN RUSSIA: FOLLOWING SOCIOLOGICAL (FIELD) RESEARCHES
}

\author{
Sergey A. Vorontsov. ${ }^{1}$ \\ Alexey Y. Mamychev. ${ }^{2}$ \\ Alexander V. Ponedelkov ${ }^{3}$ \\ Veronika V. Kolesnik $^{4}$ \\ Natalia A. Boyko ${ }^{5}$
}

\begin{abstract}
This paper presents the materials of sociological (field) research devoted to the problems of combating corruption at the state and municipal levels, as well as the analysis of data and expert opinions obtained in the course of field research. The sociological study was conducted in the form of a survey of experts in thirteen constituent entities of the Russian Federation, in which more than 1000 people were interviewed. On the basis of the data obtained, the authors substantiate the need for the adequacy
\end{abstract}

and effectiveness of the fight against corruption in Russian society to strengthen the influence of ethical and moral norms on the observance of prohibitions, restrictions, and requirements established in order to combat corruption, as well as the development of additional mechanisms and tools for preventing corruption manifestations. At the same time, it is substantiated that the adopted anticorruption norms require not only legalization, but also legitimation, that is,

\footnotetext{
${ }^{1}$ Doctor of Law, Professor, Acting Director of the Scientific and Training Center for Combating Corruption of the Institute of Law and National Security of the Russian Academy of National Economy and Public Administration under the President of the Russian Federation, Moscow, 119571, Russia. e-mail: raven_serg@mail.ru, https://orcid.org/0000-0002-1152-8244

2 Doctor habil. in political science, PhD in legal science, Head of the laboratory of political and legal research, Lomonosov Moscow State University, Professor, Vladivostok State University of Economics and Service.mamychev@yandex.ru.ORCID 0000-0003-1325-7967

${ }^{3}$ Honoured Scientist of the Russian Federation, Doctor of Political Sciences, Professor, Head of the Laboratory for Problems of Increasing the Efficiency of State and Municipal Governance of the South Russian Institute of Management being a branch of the RANEPA under the President of Russia. ponedelkov@uriu.ranepa.ru, https://orcid.org/0000-0002-5447-1647

${ }^{4} \mathrm{PhD}$ in Legal Sciences, Professor, Department of Civil Law in the Rostov Branch of the Russian State University of Justice, $\mathrm{k}$ _fp3@mail.ru, https://orcid.org/0000-0002-9918-5687

${ }^{5} \mathrm{PhD}$ in Legal Sciences, Head of the Department of Constitutional and Administrative Law in the Institute of Service, Tourism and Design (branch) of the Federal State Autonomous Educational Institution of Higher Education "North Caucasus Federal University”, , boikonatali@ mail.ru, https://orcid.org/0000-0003-37701436
} 
recognition and support by citizens and society of this work as a whole. The authors are convinced that the combination of these two components can increase the effectiveness of the prevention of corruption offenses in the Russian Federation. In addition, the work separately examines the anticorruption legislative initiatives of political parties and social movements, their significance and role in the fight against corruption interaction in society.

Keywords: anti-corruption policy, power, state, corruption, law, society.

\section{INTRODUCTION}

Systematic work to combat corruption continues in the Russian Federation. In recent years, the necessary legal framework has been created; anticorruption standards have been developed; a system of bodies implementing anti-corruption technologies has been formed; anticorruption education technologies and additional education of state and municipal employees have been introduced; the transparency of the measures taken has significantly increased, regardless of the official position of persons arrested for committing corruption crimes. The volume of work done on combating corruption was positively assessed by the OECD Working Group, which considered the possibility of transferring the Russian Federation to the third phase of the Monitoring the implementation of the OECD Convention on Combating Bribery of Foreign Public Officials in International Business Transactions. Such a transition will be possible if "promises and offers of bribes" would be enshrined in the Criminal Code of the Russian Federation until October 2020 as separate corpus delicti and the exclusion from legislation of provisions for the possibility of exemption from criminal liability in connection with active repentance in the event of bribery of a foreign official.

In 2019, a resolution of the Plenum of the Supreme Court in the Russian Federation was adopted to amend resolutions on bribery cases(Resolution of the Plenum of the Supreme Court in the Russian Federation dated December 24, 2019). This resolution expanded the list of instruments for accumulating funds and carrying out payment transactions, which can be used for settlements with 
corrupted officials (the concept of "electronic wallet" was introduced), clarified the concept of "mediation in bribery and corrupted business practices", as well as tightened requirements for the legality of any operational investigative means: so, now, regardless of whether the defendant admits his/her guilt, the court must check the legality and validity of each such operational-search activity in order to assess the evidence obtained in the course of those operational-search activity.

Two draft laws have been submitted to the State Duma providing for the consolidation in the Criminal Code and the Code of Criminal Procedure of provisions on the criminalization of illegal enrichment of officials and the introduction of necessary amendments to other regulations. A draft law aimed at improving anti-corruption standards for employees of public corporations is under consideration. If this draft law is adopted, its norms will provide for:

- extension of anti-corruption restrictions, prohibitions and obligations to employees of organizations controlled by state corporations, as well as organizations created to fulfil the tasks assigned to federal state bodies, and state bodies of a constituent entity of the Russian Federation and local governments;

- the establishment of criteria for classifying legal entities as entities created to fulfil the tasks assigned to state bodies and local self-government bodies;

- unification of the provisions of laws related to the receipt of gifts and remuneration by various categories of officials, in particular, the establishment of a list of allowed gifts received in connection with the performance of official duties;

- expanding the list of disciplinary measures for persons holding state and municipal positions, and establishing mechanisms for applying such measures(https://anticor.hse.ru/main/ne ws_page/antikorruptsionnye_itogi_2019 ) .

A significant amount of work was carried out by law enforcement agencies, which in 2019 sent to the court for consideration on the merits of 6468 criminal cases on 11,664 crimes. The following crimes prevail among those that were incriminated to the defendants in these criminal cases: giving and 
receiving bribes, various types of fraud, misappropriation and embezzlement. 6902 persons accused were brought before the court in these criminal cases. Thanks to the work of law enforcement agencies, damage from corruption crimes was compensated for 2.47 billion roubles. The property of the accused persons was also arrested for 12.9 billion roubles to ensure compensation for the harm caused.( https://sledcom.ru/news/item/1417917).

At the same time, in 2019, the number of corruption-related crimes in our country increased by $1.6 \%$, the number of bribes increased by $10.7 \%$ and the volume of mediation in bribes increased by $32.5 \%$.( The number of identified bribes in Russia in 2019).

\section{METHODS AND MATERIALS}

In order to study the reasons and factors contributing to the preservation of corruption relations, the peculiarities of the perception by the population of corruption in the modern period, and also to establish the most effective ways to counter this phenomenon, on April 17, 2020 in the city of Rostov-on-Don the Laboratory for Problems of Increasing the Efficiency of State and Municipal Management of the South Russian
Institute of Management being a branch of the RANEPA (Rostov-on-Don) has held a Scientific and Practical Conference with international participation "Combating Corruption at the State and Municipal Levels in Modern Russia" in the video conference mode.

As part of the preparation of the above conference, in February-March 2020, the Laboratory for Problems of Increasing the Efficiency of the State and Municipal Management in the South Russian Institute of Management at the Russian Presidential Academy of National Economy and Public Administration (RANEPA) conducted a sociological study in the form of a survey of experts from 13 constituent entities of the Russian Federation: in the Rostov, Volgograd, Sverdlovsk, Chelyabinsk, Kurgan, Smolensk; Krasnodar regions; Altai and Primorsky territories; Tatarstan, Karachay-Cherkessia, Karelia, and Komi republics. A total of 1080 people were interviewed.

An analysis of the sociological survey results in the Rostov region, in which 270 experts took part, is presented in the context of this paper.

Of them, there were $16.7 \%$ aged up to 29 years; $32.3 \%$ from 30 to 49 
years old; $32.5 \%$ from 50 to 59 years old; and $18.5 \%$ aged 60 and older.

By gender, there were $45.6 \%$ of men, and $54.4 \%$ of women.

By occupation:

- Representatives of public authorities and local self-government $23.7 \%$;

- Labourers in the field of science and education - 12.8;

Legal professionals (advocates, lawyers) - 12.4\%;

- Representatives of the judicial system and law enforcement agencies 8.2

- Members of public organizations - $16.9 \%$;

- Members of political parties $12.4 \%$

- Media representatives $13.6 \%$.

By the length of service in this position:

- Up to 5 years - $20.3 \%$;

- From 5 to 10 years old $22.4 \%$

- From 10 to 20 years old $26.2 \%$
- From 20 to 30 years old - 23\%;

- Over 30 years $-8.1 \%$.

The formulation of the questions and the answer options are set out in the wording proposed to the respondents. The data is given as a percentage of the actual number of responses.

Results of the sociological (field) research.

An analysis of the results of a sociological survey of experts showed that:

1. Corruption is currently not perceived as the most acute problem of concern to the population. The experts ranked the poor quality of the roads; deterioration of the ecological situation; high prices for goods in markets and shops; low wages; shortage or poor condition of hospitals, clinics and health posts; problems in the field of housing and communal services, employment and problems in the improvement of the territories of municipalities, corruption in the authorities in the higher ranking positions (Fig. 1). 


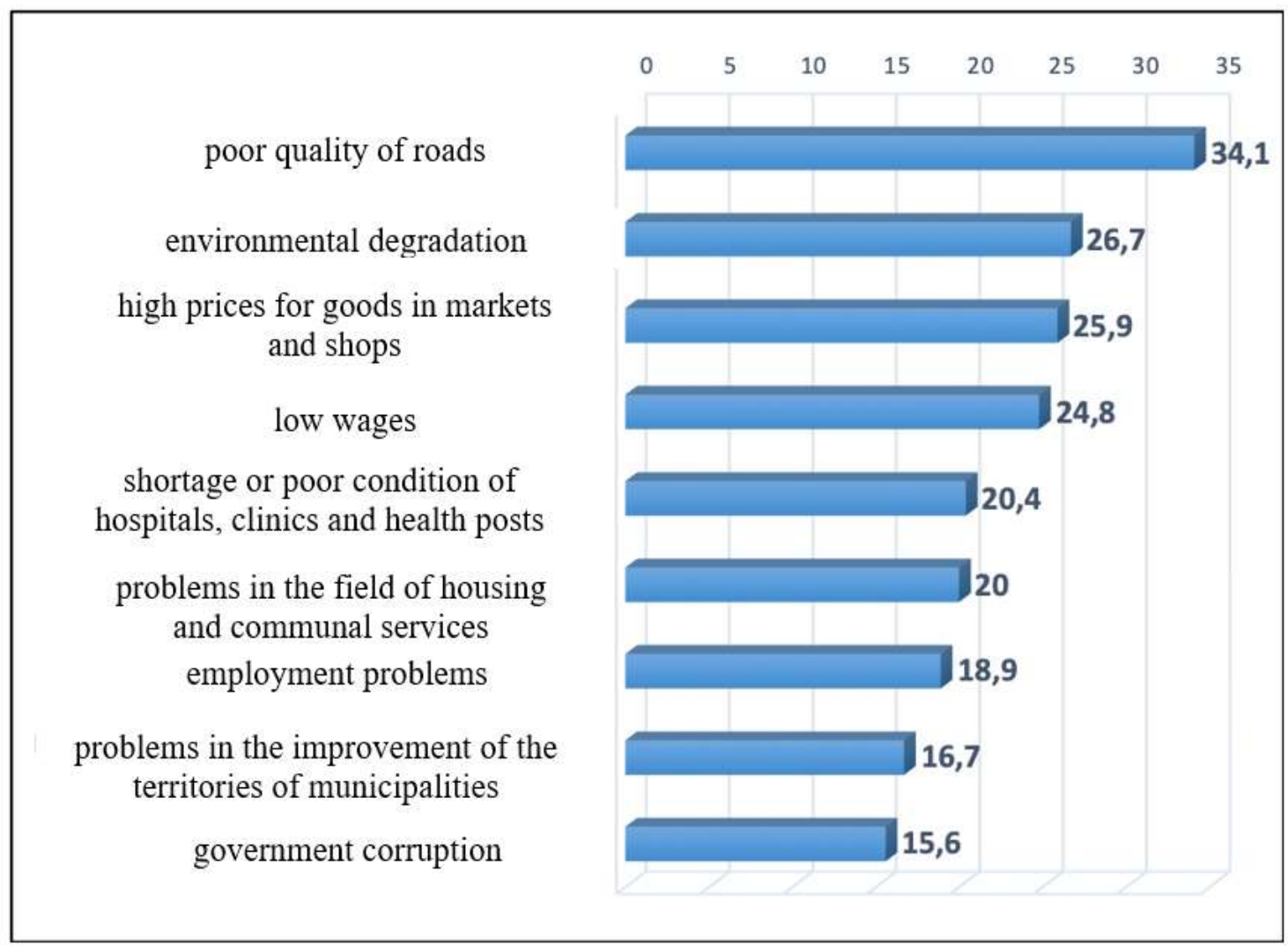

Fig. 1. Which of the following problems are most acutely perceived by the population in your area (city)

2. It is traditional for our country, that almost half of the experts perceive corruption as receiving or giving a bribe. The experts put the use of official position for personal gain in the second rank position. Attention should be drawn to the fact that gifts to officials were placed in the third rank position, which may indicate the effectiveness of anti-corruption education, because a few years ago many citizens did not consider the gifts as a manifestation of corruption. (fig. 2) 


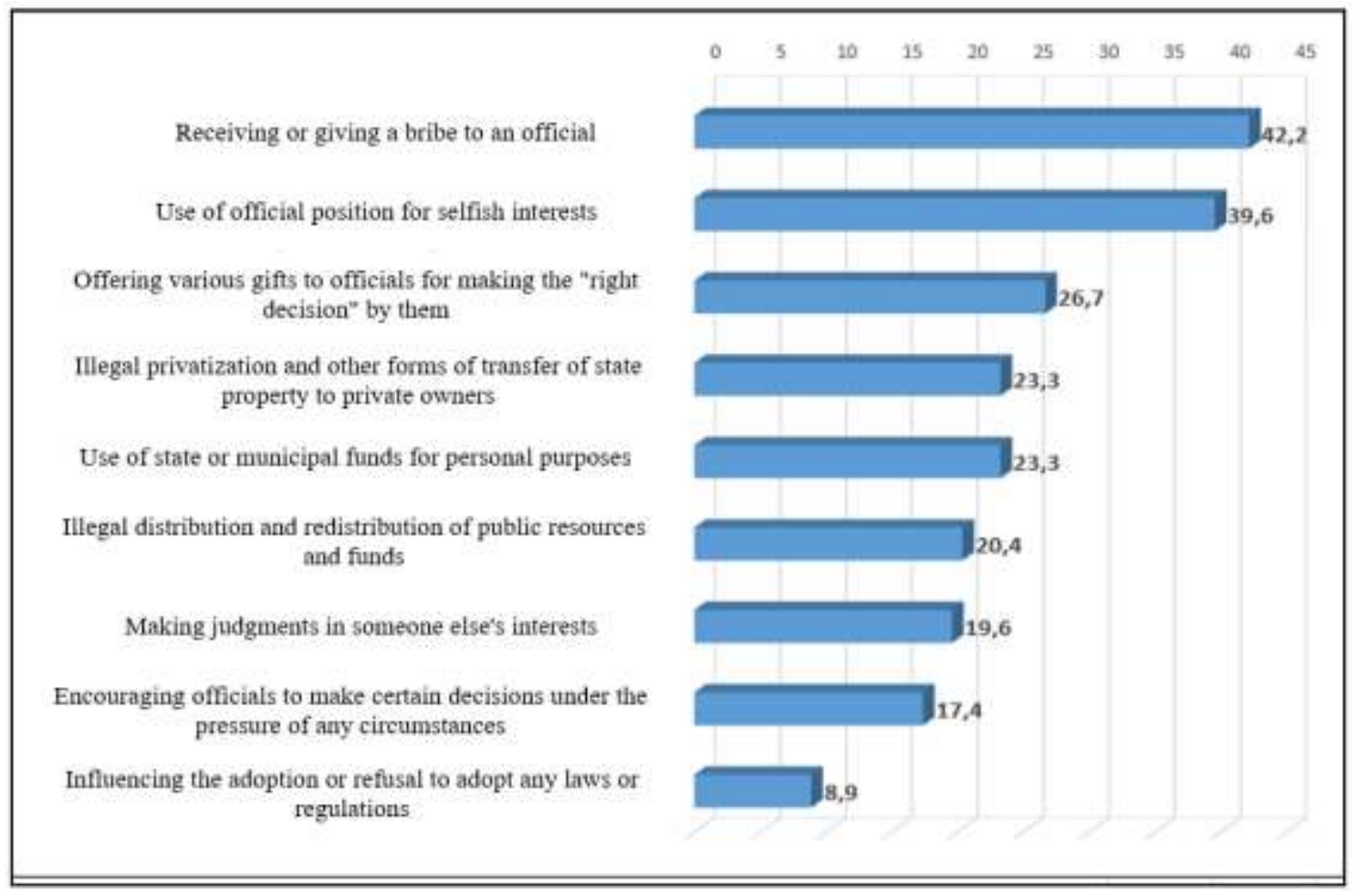

Fig. 2. What is the basic understanding of the content of corruption term in modern Russian society?

3. Despite the fact that in recent years appropriate standards and tools have been introduced into anticorruption practice allowing timely identification and prevention of corruption risks, the experts put in the first rank position the "insufficiently strict control over the actions of officials, and also their income and expenses" when characterizing the causes of corruption. The second rank position is occupied with "inadequacy of punishment for the facts of corruption", which means the lack of "inevitability of punishment" in combating corruption. The society has formed a request to ensure the adequacy of punishment, but, according to experts, it does not work in many cases concerning high-ranking corrupted officials. The experts brought "low wages of public sector workers" to the third position, which confirms the words of one of the heroes by Berthold Brecht: "bread is first, and morality is second"(https://www.litprichal.ru/work/ 318155).

Also noteworthy is the fact that experts pointed to a low level of legal 
culture among the population as a significant cause of corruption (5th rank position), which indicates the need to intensify anti-corruption and legal education, and to introduce progressive forms of this activity. The instability of the economic situation and the underdevelopment of civil society were named as the 6th and 7th positions (fig. $3)$.

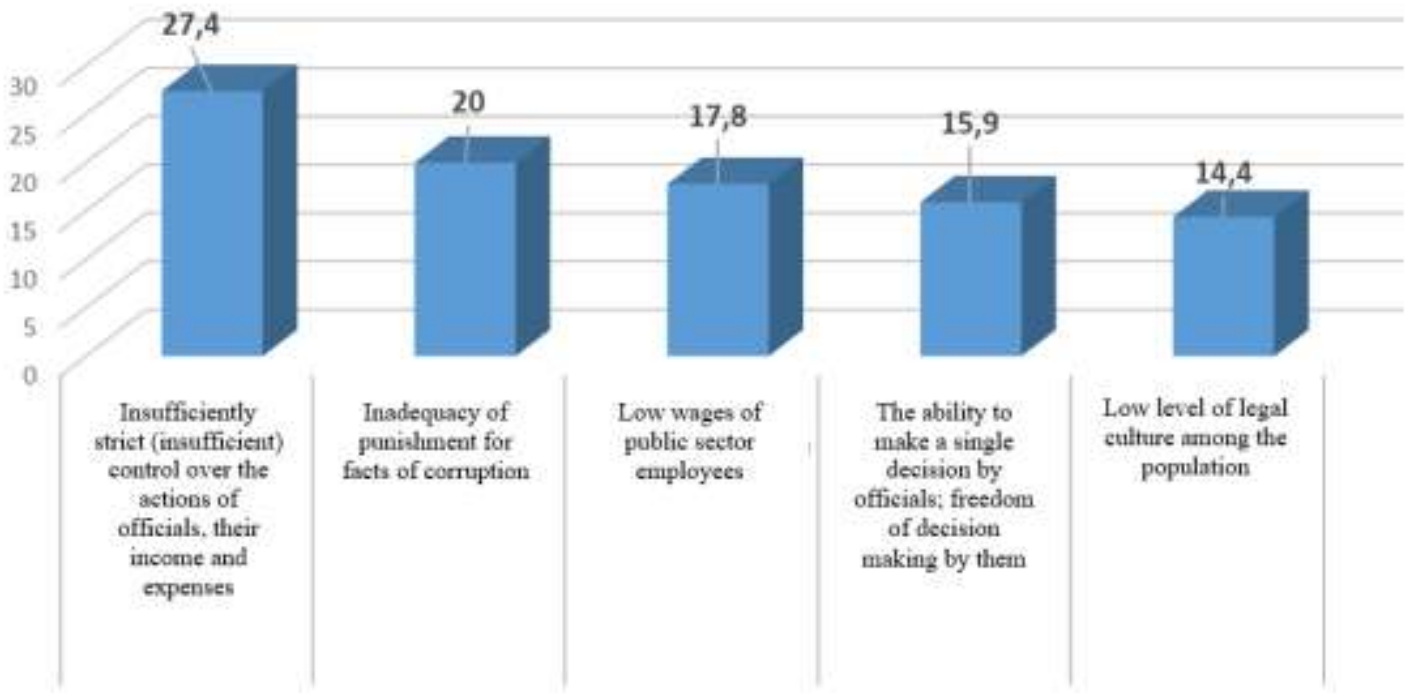

Fig. 3. What are the causes of corruption in your opinion?

4. Experts see the main danger of corruption for an individual, society, and the state in the fact that corruption reduces to nothing the level of political loyalty of citizens to the state and its political leaders, since the latter do not comply with the law and their actions contradict the principles of justice.

The experts put in the second rank position the statement that corruption destroys the concepts of morality, fairness and justice.
Experts see the danger of corruption in the fact that it spreads an unlawful worldview in society (nihilism). According to them, since laws are not binding for corrupted elite, it means that the laws can be disregarded by the population. And here, it is appropriate to recall the words of E.M. Primakov as the representative of the Russian political elite, who, speaking about the foundations of Russia's economic struggle in the 21 st century, pointed out a number of unresolved 
problems in our country, emphasized the level of "corruption, which manifests itself everywhere, both in the practice of government orders and tenders, and in the framework of unfounded claims from inspection bodies, and the favouritism of civil servants who patronize those companies that may be competitors of potential investors, etc." (Primakov,
2011). Therefore, the desire to shift the brunt of the fight against corruption onto the officials themselves is counterproductive. To this end, it is necessary to actively use public institutions to prevent corruption manifestations destroying the atmosphere of invincible corruption (Fig. 4)

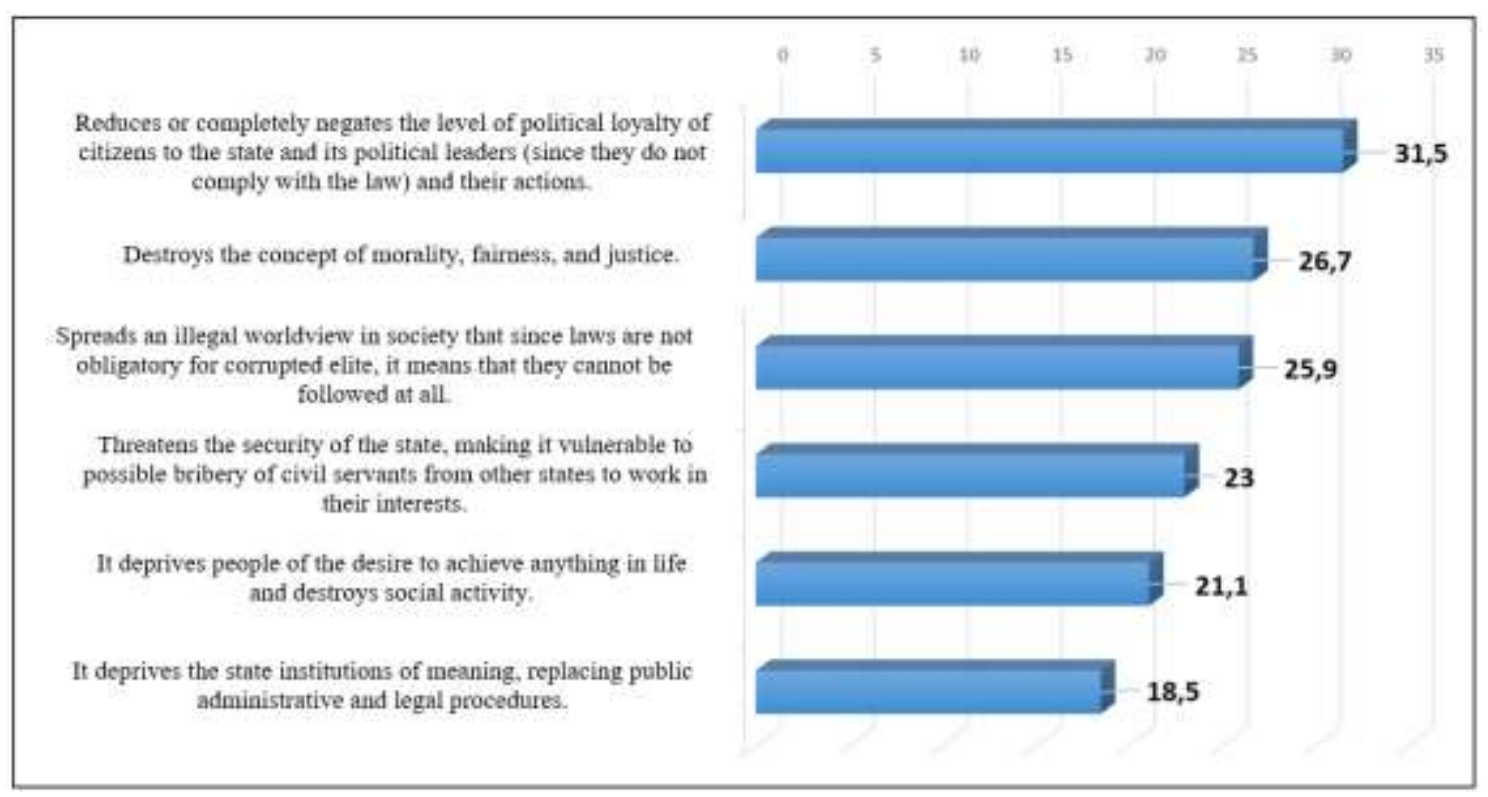

Fig. 4. Why corruption is dangerous for individuals, society and the state?

5. Describing the real level of corruption in Russia, almost half of the experts ranked the first position with the statement that corruption is currently one of the main unsolved problems in our country; the level of its prevalence in state structures is very high. In contrast to them, a third of the experts noted that in recent years this level has dropped significantly.

The opinion of every fifth expert is surprising that the problem of corruption in Russia has been practically eradicated and only isolated special cases of bribery occur (Fig. 5) 


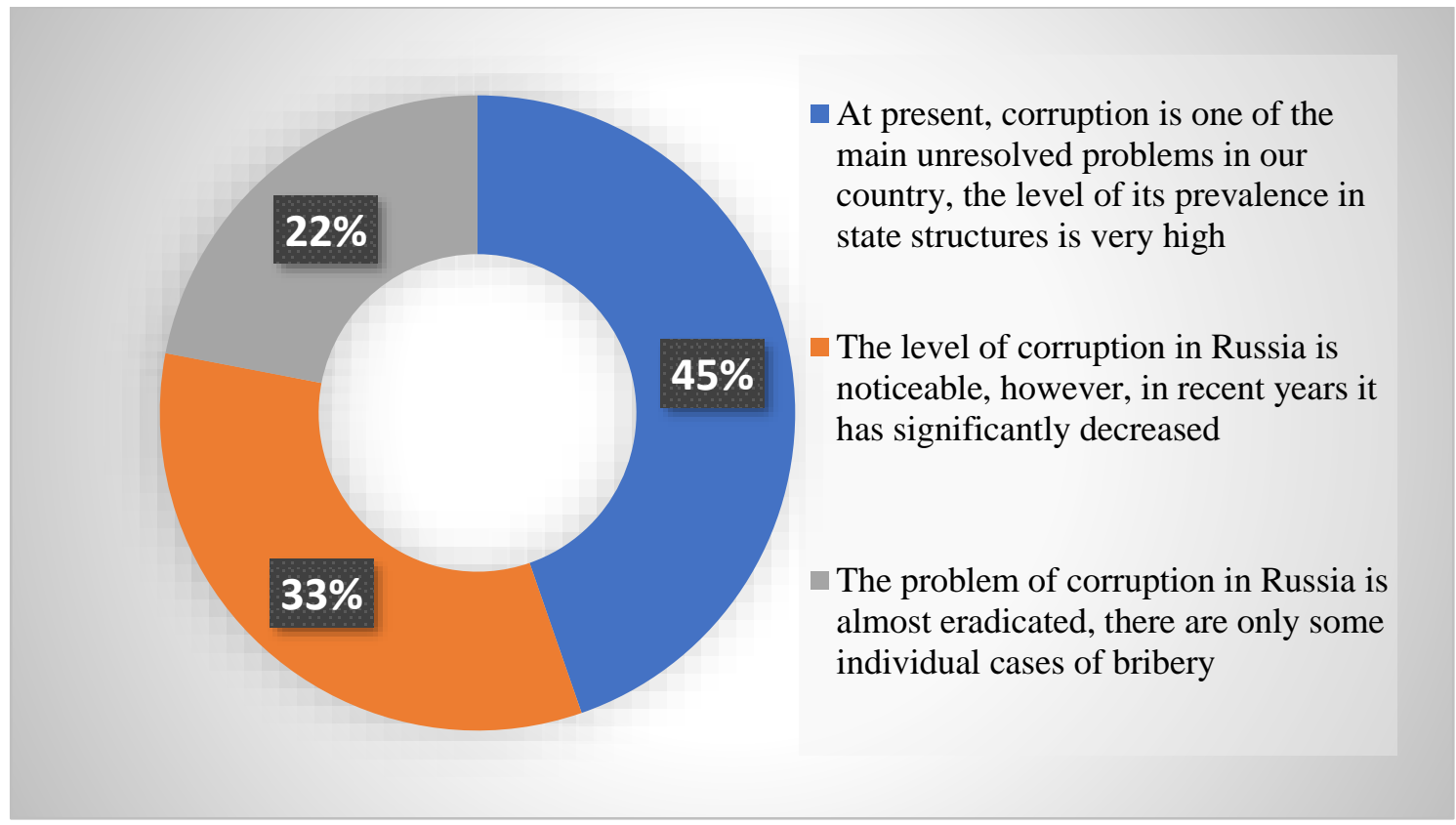

Fig.5. Which of the following judgments best reflects the real level of corruption in Russia as a whole?

6. More than half of the experts believe that corruption either has no effect on their life, or has little impact. Only every fourth expert is convinced that corruption affects the entire spectrum of relations in the state and society; therefore, it also affects the life of individuals. (Fig.6)

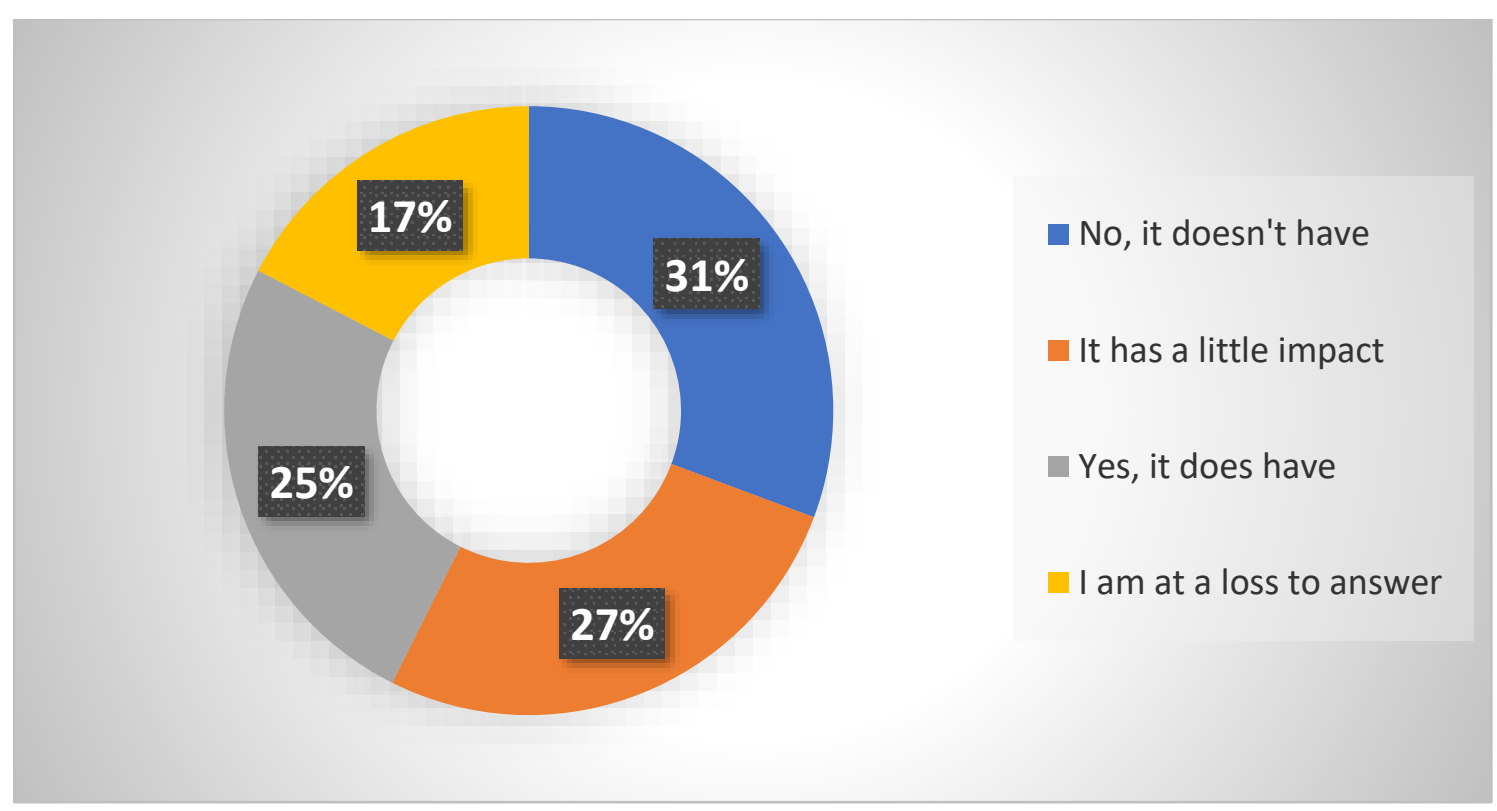


Fig.6. Does corruption have an impact on your life?

7-9. When analysing the impact of corruption on various spheres of life (economy, politics, business), the opinions of experts were divided almost in half: half of the experts believe that corruption has an impact on these areas; the other half is convinced that it does not, or has a slight impact. In any case, such assessments can be explained by a real decrease in the level of corruption in the country, or by the population's "getting used to" the existence of corruption mechanisms as an inevitable element of modern Russian life. (Fig.79)

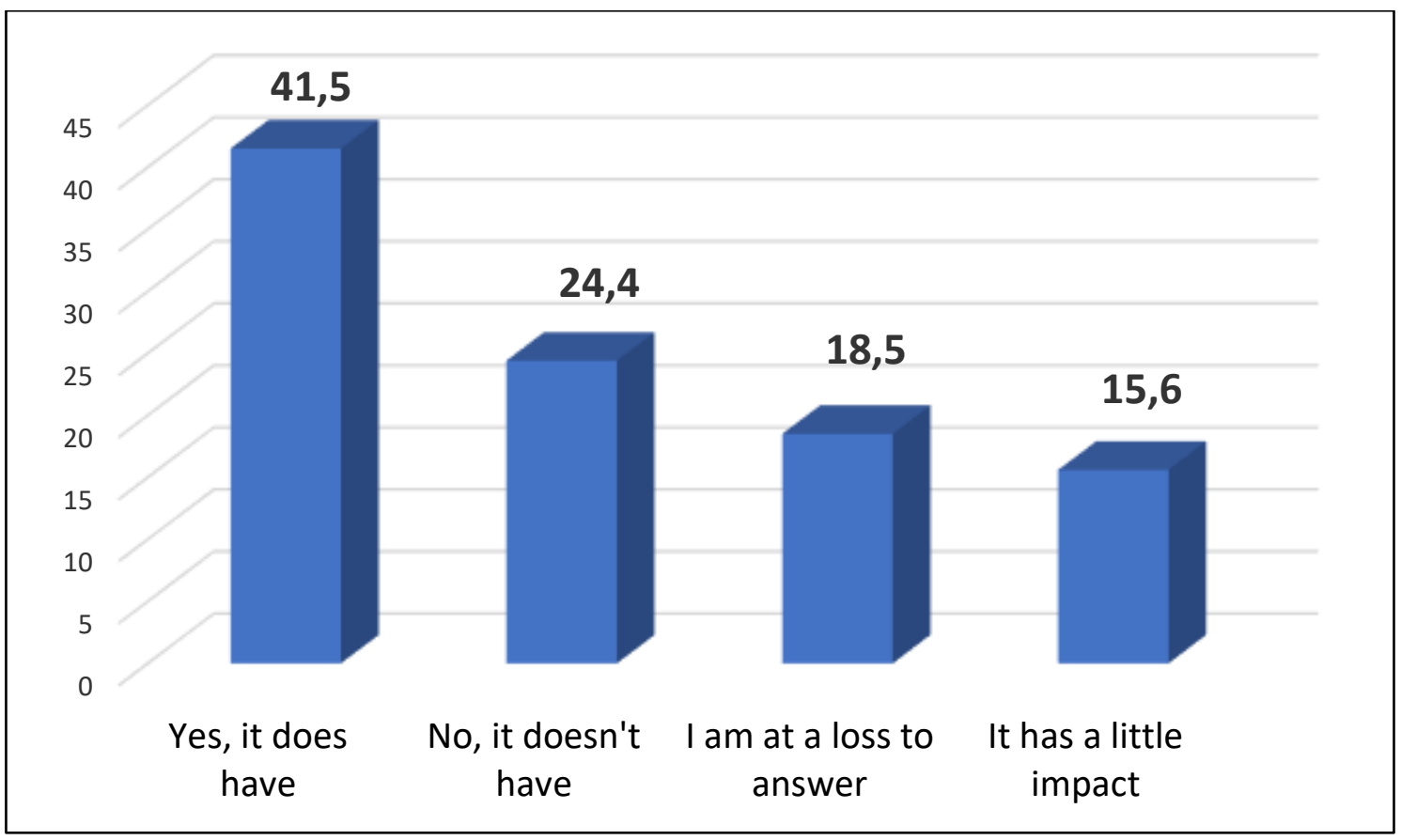

Fig.7. Does corruption have an impact on the business climate? 


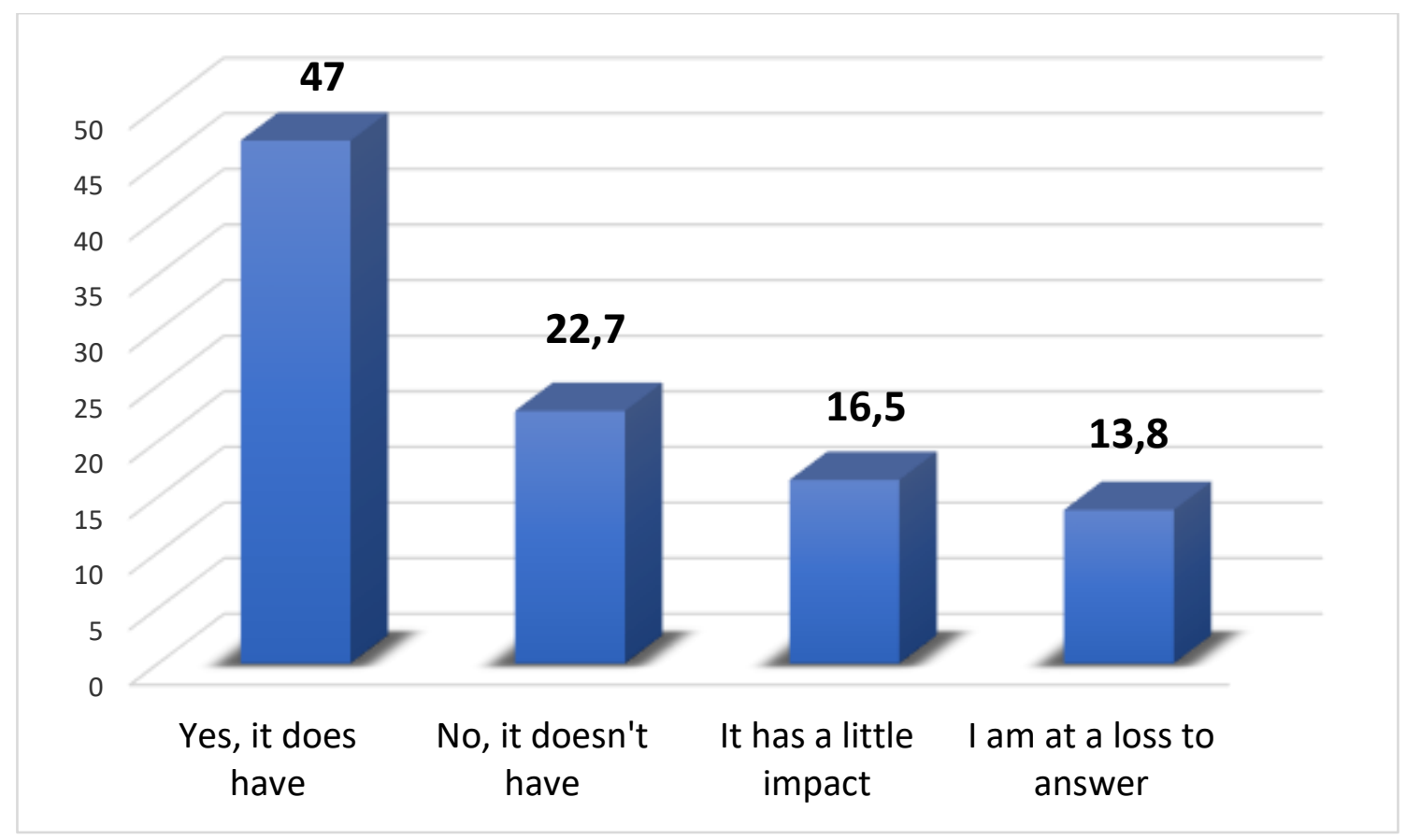

Fig.8. Does corruption affect the political system?

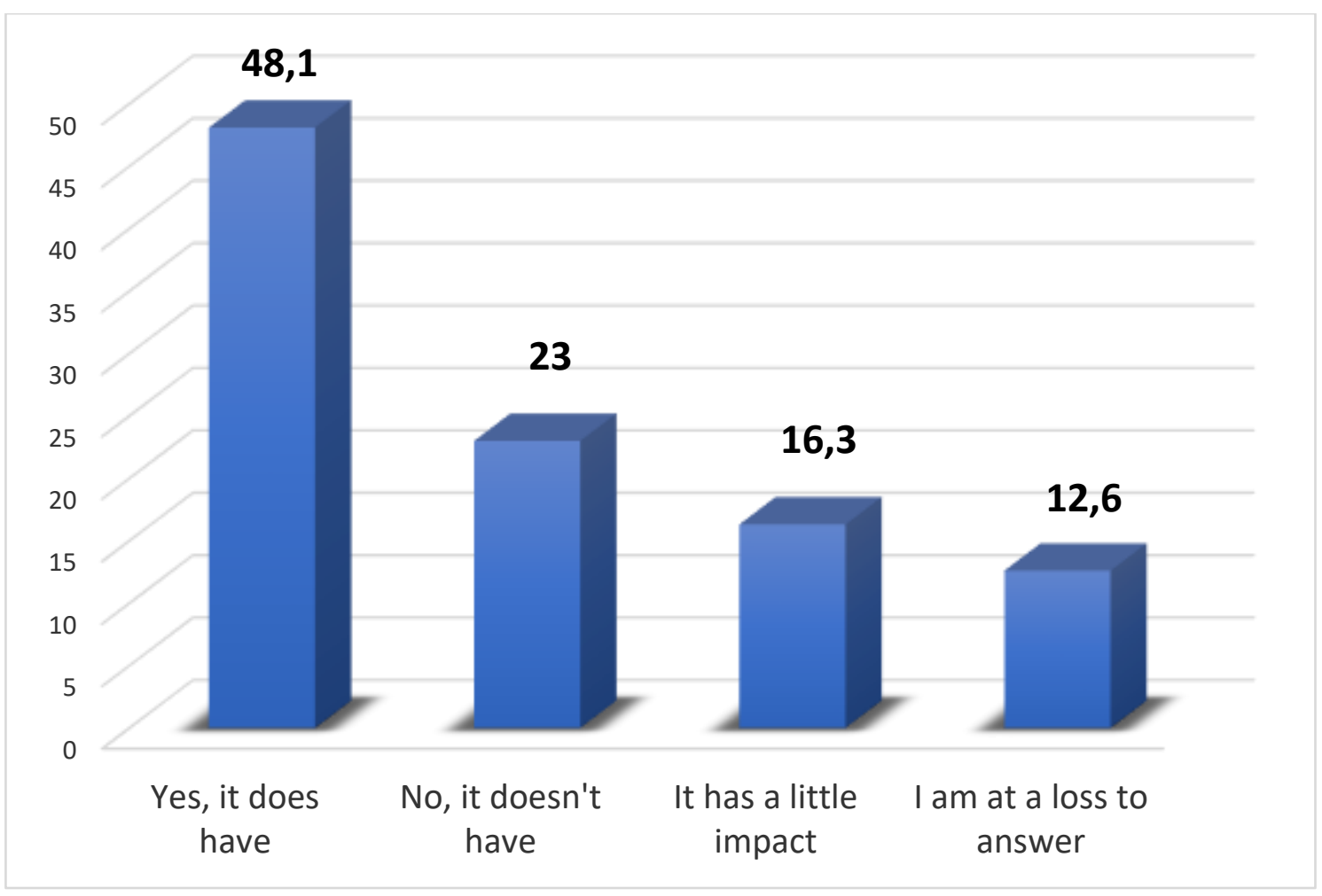

Fig.9. Does corruption have an impact on the economy? 
10-11. For example, the level of corruption in the Rostov region as a federal subject of the Russian Federation was assessed by $29 \%$ of experts as medium, as many as low. Moreover, in percentage terms, the level of corruption in the federal subject turned out to be lower than that indicated by them in Russia (38.9\%). $27 \%$ of experts believe that the level of corruption in the region is high.

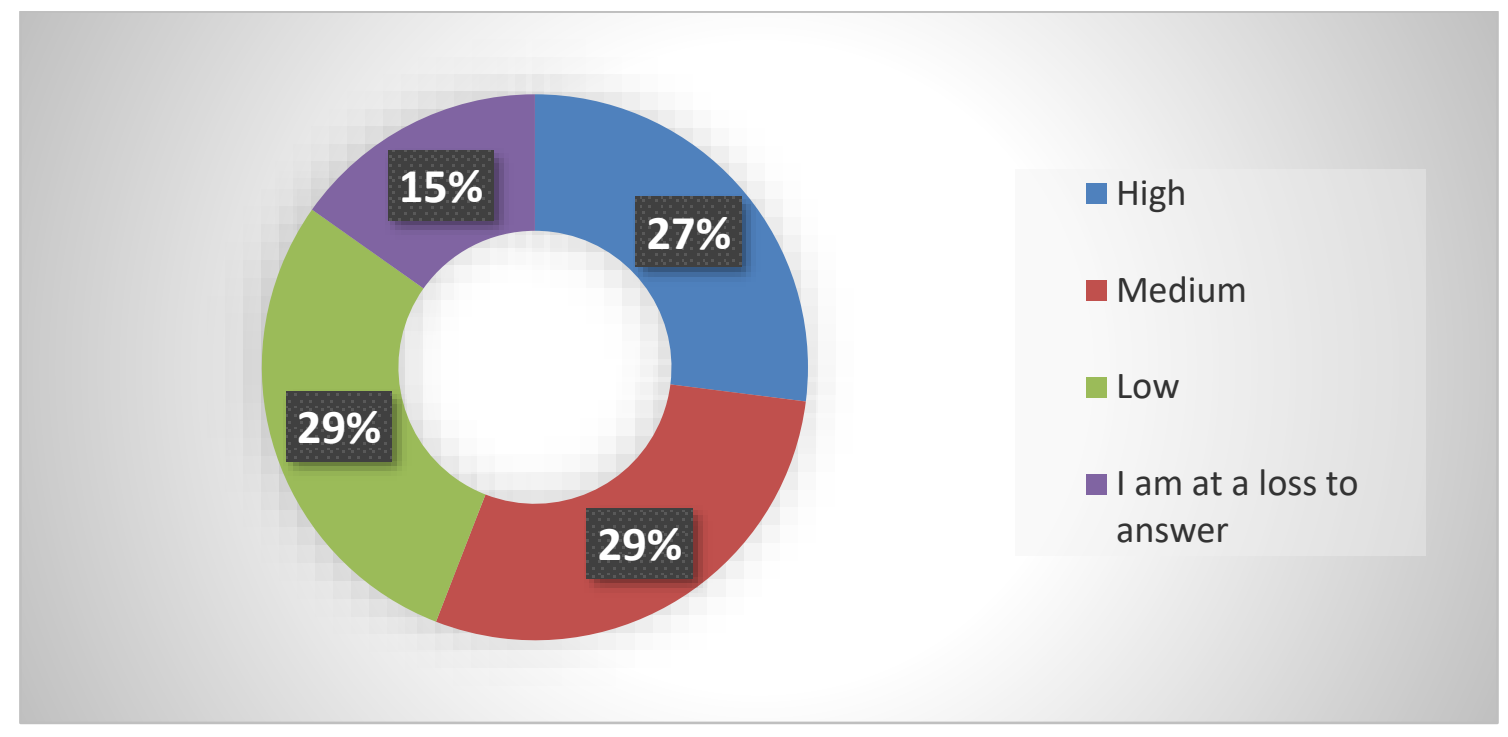

Fig. 10. How do you assess the level of corruption in your federal subject?

Compared to $2019,33.3 \%$ of experts noted that the level of corruption remained at the same level; $27.4 \%$ believe that the level of corruption has decreased; $17.4 \%$ of experts believe that the level of corruption in the subject has increased significantly (Fig. 10-11). 


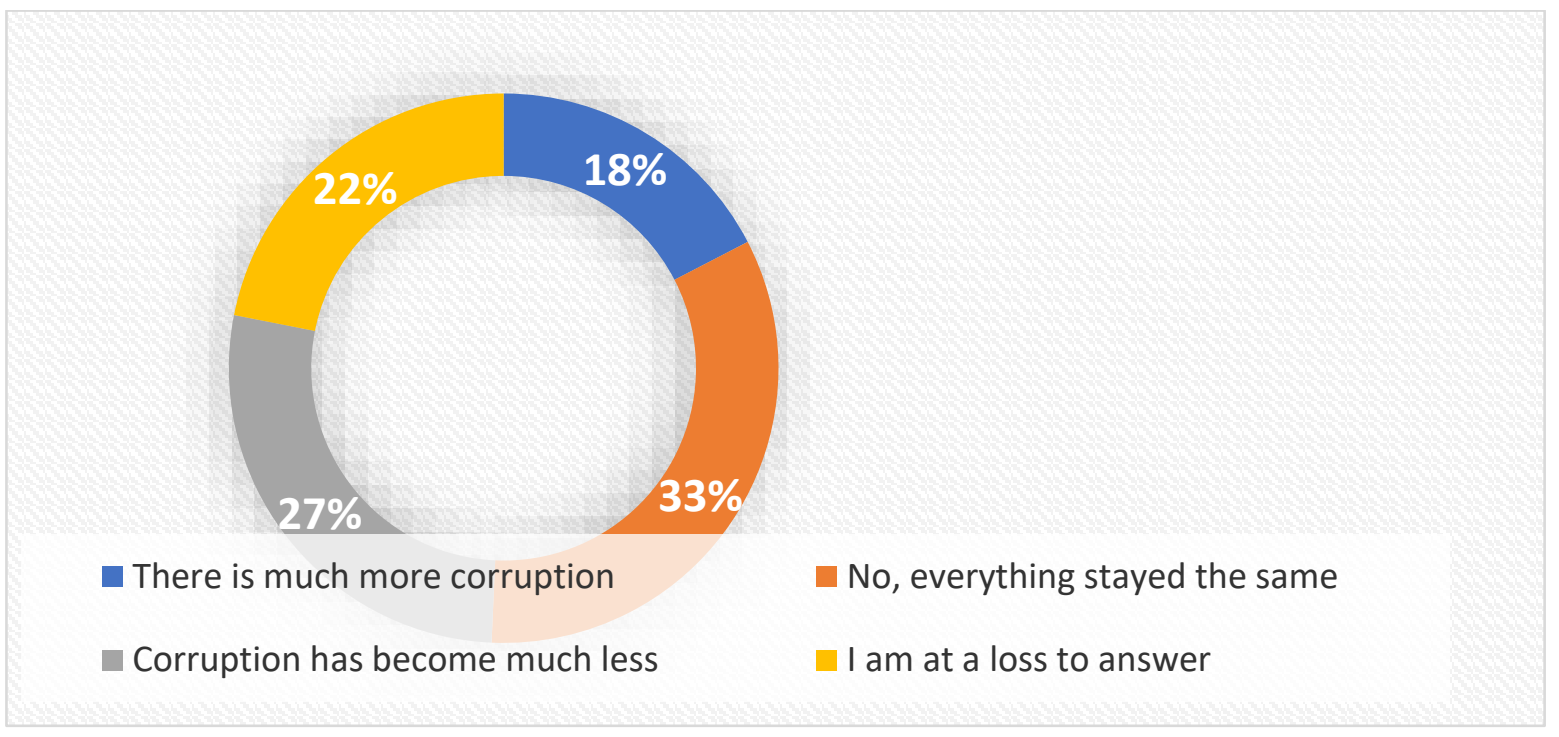

Fig. 11. How has the level of corruption in your region changed over the past year?

12-13. $38.9 \%$ of experts rated the level of corruption in the Russian Federation as high; $27.4 \%$ believe that the level of corruption in the country is average, and $25.2 \%$ assessed it as low.

$36 \%$ of experts believe that the level of corruption in the Russian
Federation has not changed in 2019. $26.3 \%$ noted a decrease in the level of corruption. Every 5th respondent is convinced that corruption has become much more. (Figs. 12-13). 


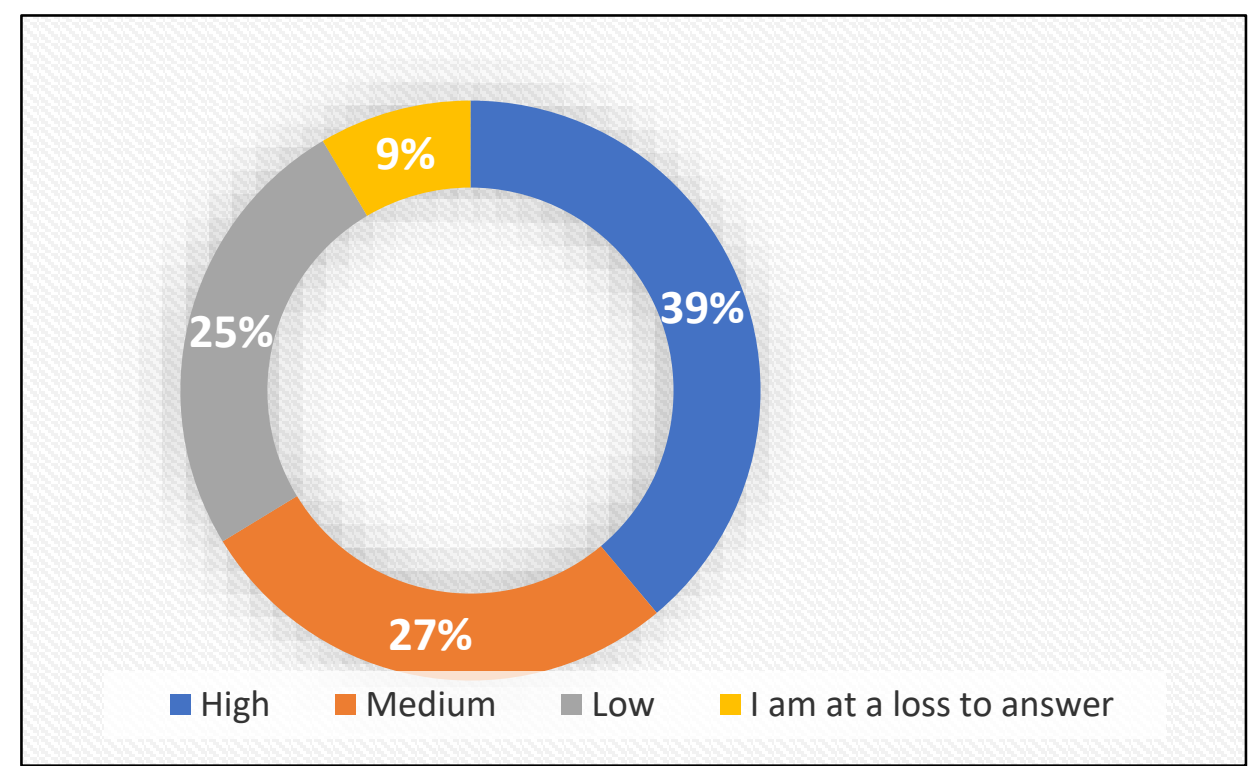

Fig. 12. How do you assess the level of corruption in the Russian Federation?

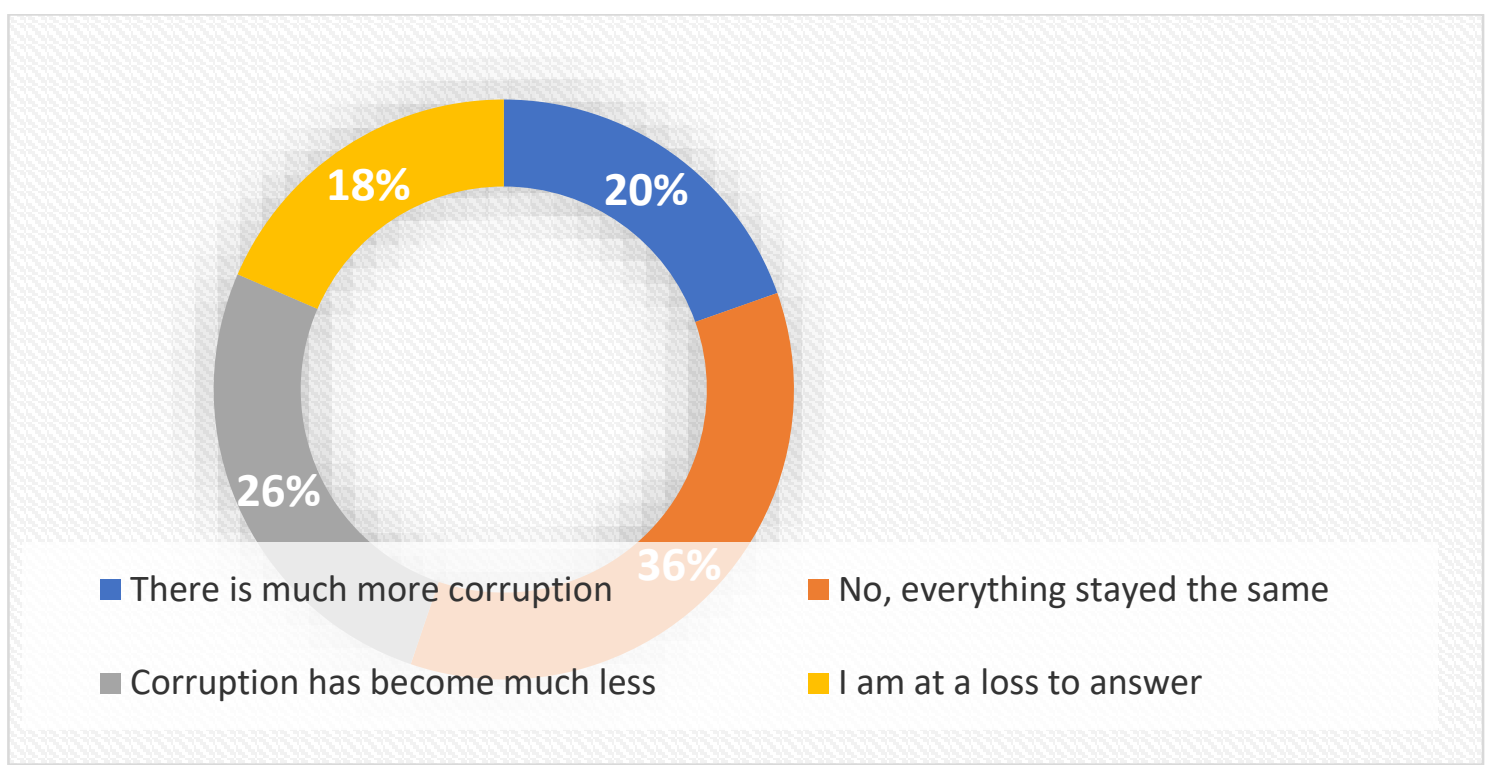

Fig. 13. How has the level of corruption in the Russian Federation changed over the past year?

14. Experts expectedly put traffic police officers in the first rank position among the representatives of the most corrupted professions, traditionally occupying the top lines in most sociological polls and followed by officials allocating plots for commercial activities and housing construction, employees of local administrations, employees of the prosecutor's office, 
military registration and enlistment offices, employees of the Federal Penitentiary Service, customs authorities, Rostpotrebnadzor, State Fire Supervision, judges of district and regional courts, doctors and other medical workers. Teachers and school principals mentioned in the reports of law enforcement agencies as the most corrupted category, are not so, in the opinion of experts, and occupy the last place in the list of corrupted professions. (Table 1).

Table 1. Even if you have not personally encountered a problem, please tell me, in your opinion, which professions are the most corrupted?

(\%)

\begin{tabular}{|c|c|}
\hline Internal affairs officers (police), incl. traffic police officers. & 27,8 \\
\hline Officials providing land plots for commercial activities. & 21,1 \\
\hline Local government officials. & 18,5 \\
\hline Officials issuing individual building permits. & 17,4 \\
\hline Employees of the prosecutor's office. & 17,0 \\
\hline Officials issuing permits for the commercial construction of residential buildings. & 16,7 \\
\hline Military enlistment office employees. & 16,3 \\
\hline Officials of regional (territorial) ministries and departments. & 15,2 \\
\hline Employees of penitentiary institutions (pre-trial detention centres, prison camps). & 14,4 \\
\hline Customs officers. & 13,7 \\
\hline District (city) court judges. & 13,0 \\
\hline Employees of the State Fire Supervision. & 12,6 \\
\hline Rospotrebnadzor (Russian Agency for Health and Consumer Rights) employees & 11,9 \\
\hline Directors (heads) of enterprises. & 11,1 \\
\hline Judges of the regional courts. & 11,1 \\
\hline Doctors and other healthcare professionals. & 11,1 \\
\hline Employees of institutions providing funeral services. & 10,7 \\
\hline University teachers. & 8,9 \\
\hline Judges of the Arbitration Court. & 8,5 \\
\hline Employees of Civil registry offices. & 7,8 \\
\hline Tax officers. & 7,8 \\
\hline $\begin{array}{l}\text { Employees of the chambers for land and property relations of regional executive } \\
\text { committees. }\end{array}$ & 7,4 \\
\hline Bailiff service officers & 6,7 \\
\hline Justices of the peace. & 6,7 \\
\hline
\end{tabular}




\begin{tabular}{|l|l|}
\hline Pension Fund employees. & 5,9 \\
\hline Heads of preschool institutions. & 4,8 \\
\hline Employees of passport and visa services. & 4,8 \\
\hline Technical Inventory Bureau (BTI) workers. & 4,4 \\
\hline Agricultural directorate workers. & 4,4 \\
\hline School teachers, school directors. & 2,2 \\
\hline I am at a loss to answer. & 2,2 \\
\hline $\begin{array}{l}\text { Others: } \\
\text { service), Elektronadzor (city electricity service) (resource supplying and utility } \\
\text { organizations); } \\
-\quad \text { Those who are engaged in antimeritocratic behavior }\end{array}$ & 0,7 \\
\hline
\end{tabular}

15. Over the past year, one third of experts have personally come across manifestations of corruption. It seems that this is an unacceptably high figure. This indicates that potential bribe-takers are not afraid of the intensification of repressive measures for corruption offenses and that anti-corruption education measures have not yet had a proper deterrent effect on officials, and, therefore, have not led to a tangible decrease in the level of perception of corruption.

16. Two thirds of the experts believe that they are not protected, or protected to some extent from "administrative arbitrariness of corrupted officials" who give orders of a corrupted nature to their subordinates, threatening them with dismissal if they do not comply. No more than a quarter of experts are convinced of their "absolute security".

It should be noted that, in comparison with previous studies, the number of citizens who will not report the facts of corruption under no circumstances has significantly decreased (14.1\%). Previously, this figure was at $30 \%$.

Every 5th expert chose the option: "I will contact the law enforcement agencies;" there is about the same number of those who are ready to use the helpline. In general, threequarters of the experts are ready to cooperate with the authorities in combating corruption. $11.3 \%$ of experts are ready to inform the authorities by an anonymous letter. 
17. Experts explain the position of citizens who refuse to inform about the facts of corruption by their fear for the safety of themselves and their loved ones, calling in their immediate environment with the name of a "denouncer or informant", as well as disbelief that real measures will be taken against corrupted officials (Fig.14).

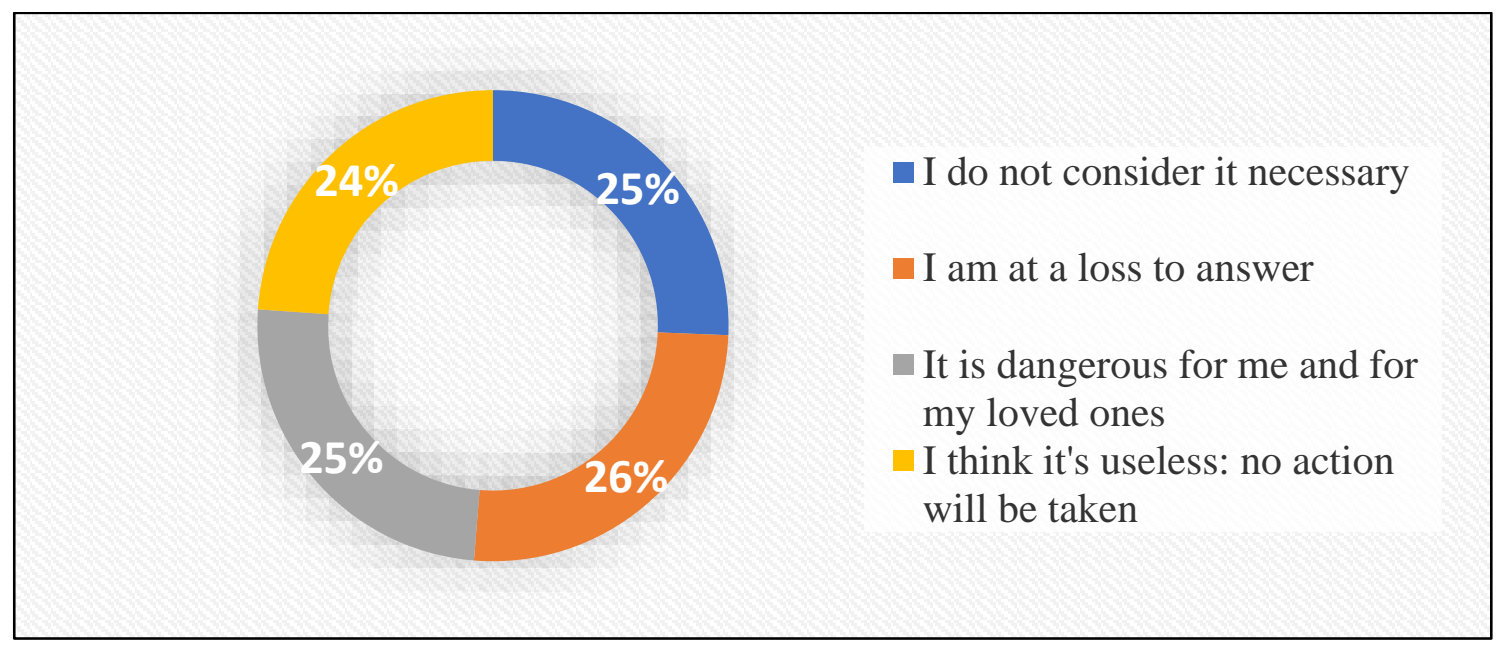

Figure 14. If you would not report the facts of corruption, please, indicate your reason

18. Answering the question, when solving what problem, or in what situation people have to bribe, experts put in the first position "the desire to resolve problems with the traffic police." In the second position, there is a desire to achieve the desired result in court; the third is the settlement of problems with a military registration and enlistment office, then, employment and promotion. In general, the list of situations in which people have to resort to using corruption mechanisms shows a wide range of real corruption risks that require the attention of state bodies and public structures involved in combating corruption. (Table 2)

Table 2. When solving what problem or in what situation do people have to bribe?

\begin{tabular}{|l|l|}
\hline Traffic police: settle a situation, get a license, etc. & 16,7 \\
\hline Courts: To achieve justice or the desired result in court. & 14,1 \\
\hline
\end{tabular}




\begin{tabular}{|l|l|}
\hline Military enlistment offices: solving problems in connection with conscription. & 12,6 \\
\hline Medicine: receiving free medical care in a polyclinic, hospital, disability registration. & 8,1 \\
\hline School: go to the desired school and complete it successfully. & 11,5 \\
\hline Job: Get the job they want or secure a promotion. & 11,5 \\
\hline $\begin{array}{l}\text { University: to enter, transfer to a more prestigious faculty, budget education, pass } \\
\text { exams, etc. }\end{array}$ & 10,7 \\
\hline Police: get help and protection. & 10,4 \\
\hline Living space: get (including social mortgage). & 10,0 \\
\hline $\begin{array}{l}\text { Penitentiary institutions (pre-trial detention centres, prison camps): when visiting } \\
\text { relatives, handing over parcels, etc. }\end{array}$ & 9,6 \\
\hline $\begin{array}{l}\text { Land plot: purchase (for summer cottages, housing construction, personal subsidiary } \\
\text { plots), registration, transfer of rights, etc. }\end{array}$ & 8,1 \\
\hline $\begin{array}{l}\text { Bodies of local self-government of a city district (municipal district): solving issues } \\
\text { related to their activities. }\end{array}$ & 8,1 \\
\hline Prosecutor's Office: obtaining legal assistance and protection. & 8,1 \\
\hline $\begin{array}{l}\text { Regional ministries and departments: solving issues related to their activities, with the } \\
\text { activities of their structural units. }\end{array}$ & 5,6 \\
\hline $\begin{array}{l}\text { Other: } \\
\text { - For all the indicated problems; } \\
\text { - - Bailiffs - bribe for the purpose of non-payment of alimony }\end{array}$ & 3,4 \\
\hline $\begin{array}{l}\text { Passport office: obtain registration at the place of residence, a passport, a foreign travel } \\
\text { passport. }\end{array}$ & 5,2 \\
\hline Customs: passing customs control, cargo transportation, etc. & 3,3 \\
\hline Pensions: early registration, etc. & 3,3 \\
\hline $\begin{array}{l}\text { Bureau of Technical Inventory: expedite service delivery; obtain documents allowing } \\
\text { for real estate transactions, etc. }\end{array}$ & 3,3 \\
\hline Real estate: formalize legal rights with the registration authorities. \\
\hline Tax office: reduce taxes, get services. \\
\hline $\begin{array}{l}\text { Rospotrebnadzor: getting help on the quality of products and other issues related to } \\
\text { their activities. }\end{array}$ & 3,3 \\
\hline Social payments: registration of benefits, payments, etc. & 3,3 \\
\hline
\end{tabular}

19. It should be noted that only every fourth expert considers giving gifts to officials as a manifestation of corruption. About the same number justify gifts by national tradition and a sincere desire to thank an official for the service rendered. $27.7 \%$ of experts 
believe that a gift is the only way to solve a problem and save time and nerves.

20. As they know, the Rostov region is a leader in the country concerning the implementation of "single window" technologies offered by MFCs (multifunctional centres for the provision of state and municipal services). This ensures "transparency" of operations, which creates certain guarantees against corruption. Almost two-thirds of the experts noted that they use services provided electronically via the Internet (payment of utility bills, traffic fines, queuing at a preschool institution, preliminary registration for obtaining a foreign travel passport, etc.). At the same time, the same number of experts indicated that they do not consider services in electronic form a guarantee against corruption, since corrupted officials find ways to illegally resolve emerging issues.

21. The expert survey showed that more than $90 \%$ of experts have information on anti-corruption measures in full or in part. Only $8.1 \%$ admitted that they did not have such information. These figures dictate the need for more active implementation of measures to educate the population against corruption.

It should be noted that in comparison with similar surveys conducted in previous years, the number of experts who are not familiar with the text of the Federal Law "On Combating Corruption" has significantly decreased. If in 2018 this indicator in the Rostov region was $26.1 \%$, then this year it is $8.1 \%$.

22. An assessment of anticorruption measures regulated by the Federal Law "On Combating Corruption" showed that less than $10 \%$ of experts consider these measures to be effective in combating corruption. More than a third of experts agree with this assessment, but note that anti-corruption measures are not always respected. Another third of experts consider corruption prevention measures rather ineffective and practically impossible to implement in practice. $19.3 \%$ of experts believe that the measures under consideration are absolutely ineffective. (Fig.15) 
I'm not familiar with the text of the law

No, the measures to prevent corruption outlined in the law are absolutely ineffective

Rather not, corruption prevention measures are practically not implemented

Rather, yes; the prevention measures outlined in the law can be effective, but they are not..

Yes, they are fully implemented and prevent the spread of corruption
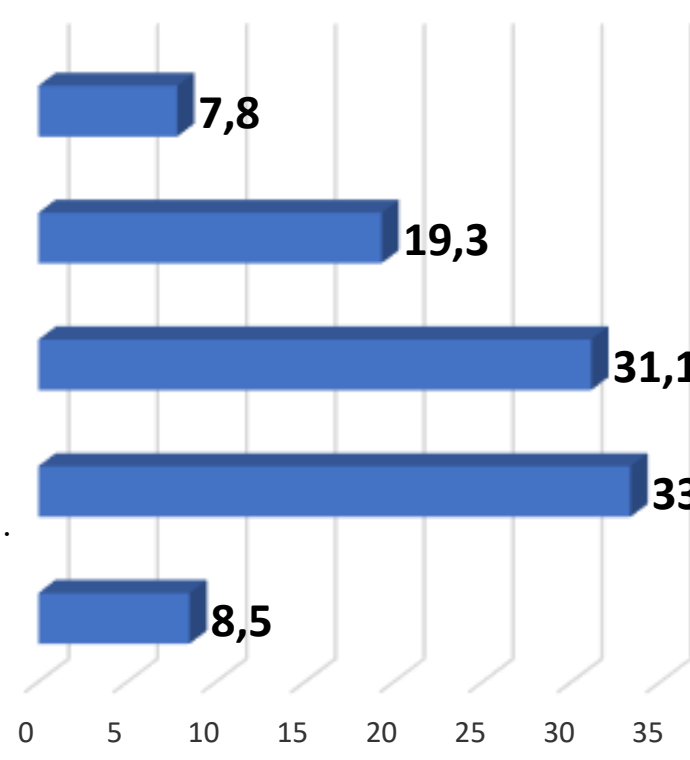

Fig. 15. Are the corruption prevention measures outlined in the AntiCorruption Law effective?

23. Experts identified the measures among those aimed at combating corruption: the removal of officials from office; the dismissal of an official convicted of corruption; bringing bribe-takers and corrupted officials to justice; improving anti-corruption legislation, and control over the income and expenses of officials.

The activities of the AntiCorruption Foundation by Alexei Navalny were noted by $3.7 \%$ of experts, which shows the lack of wide public interest in this actor. (Fig.16) 


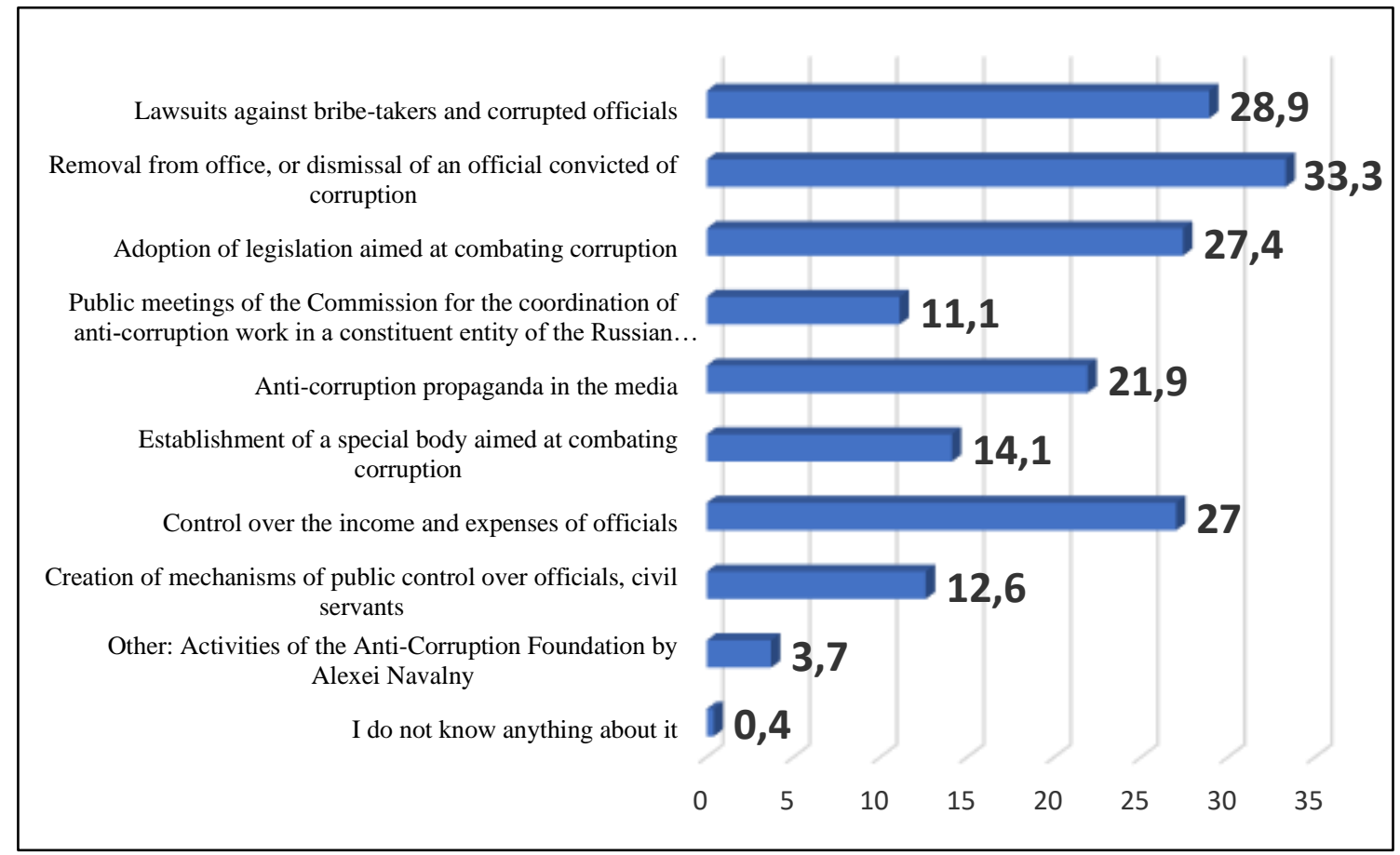

Fig. 16. What actions to combat corruption do you personally know about

24. The experts indicated newspapers, television and radio broadcasting as the main source of information on anti-corruption. This is followed by the information and telecommunications network Internet and the websites of state (municipal) authorities.

As for the federal media, only every 5th expert is satisfied with the quality and volume of information received. Two-thirds of experts believe that the information is either insufficient, or it does not cover all aspects of anticorruption issues. A similar picture exists in the local media, in which the experts' interest is lower than in the federal ones. (Fig. 17-19) 


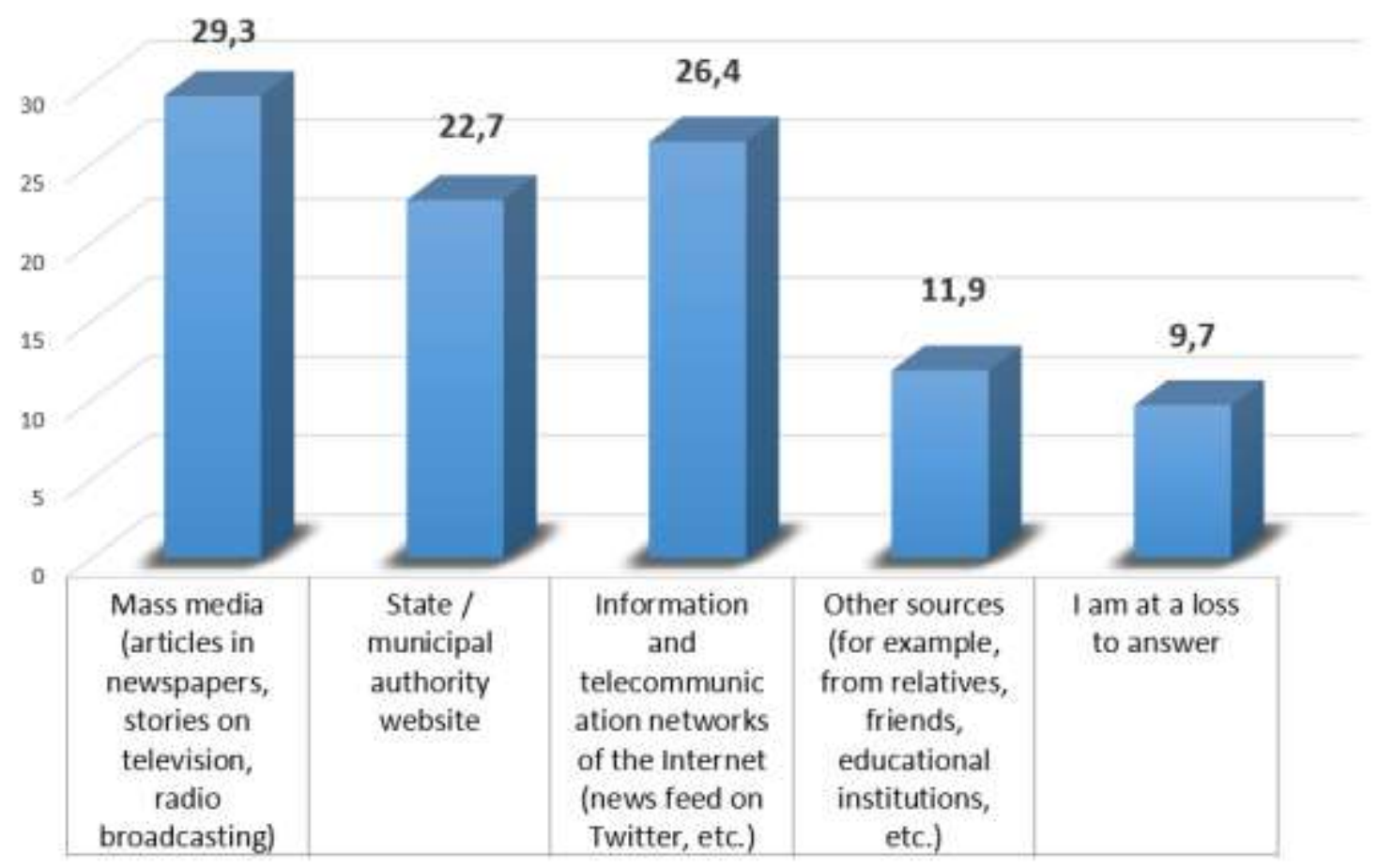

Fig. 17. Please indicate from which sources you most often receive information on anticorruption activities in your federal subject?

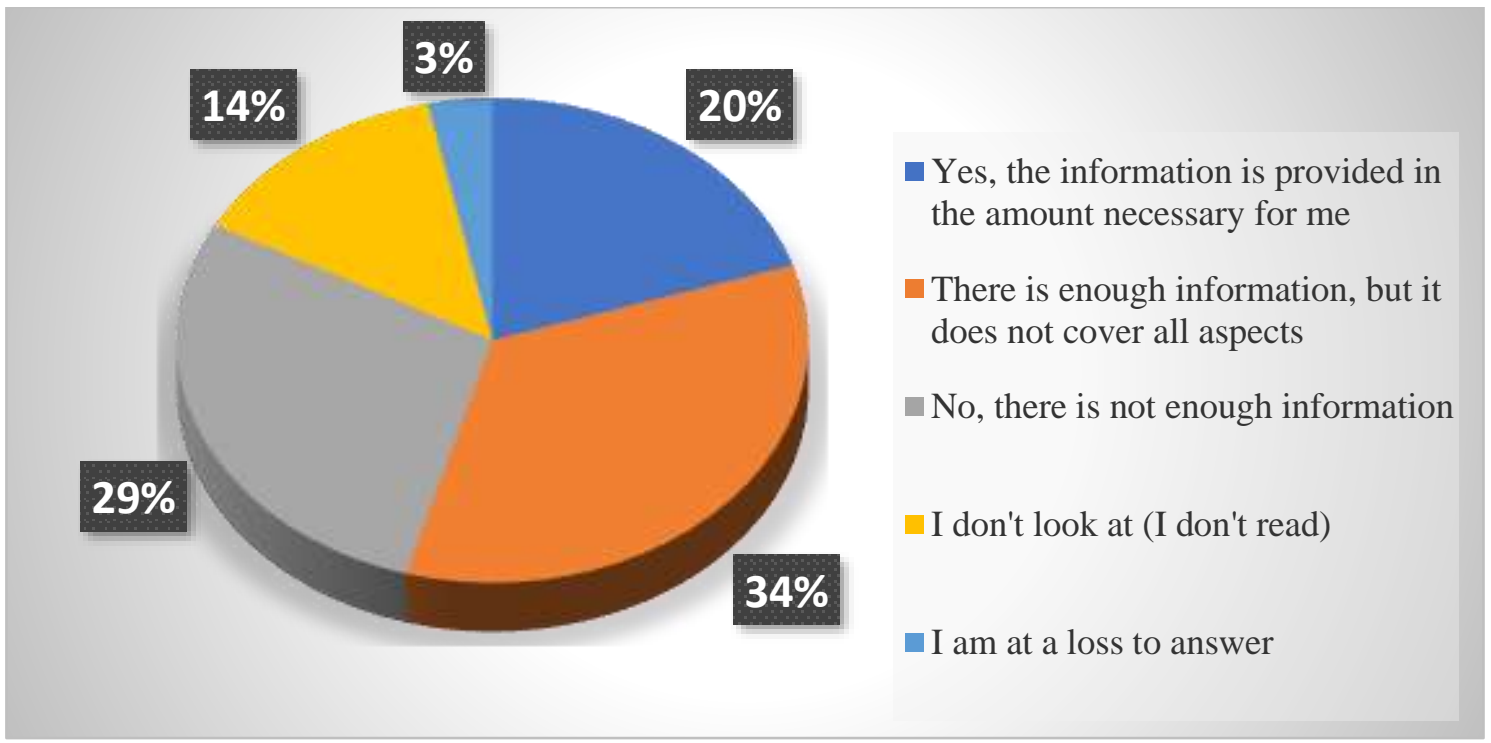


Fig. 18. Is there enough information about the anti-corruption policy in the federal media (articles in newspapers, stories on television, radio broadcasting)?

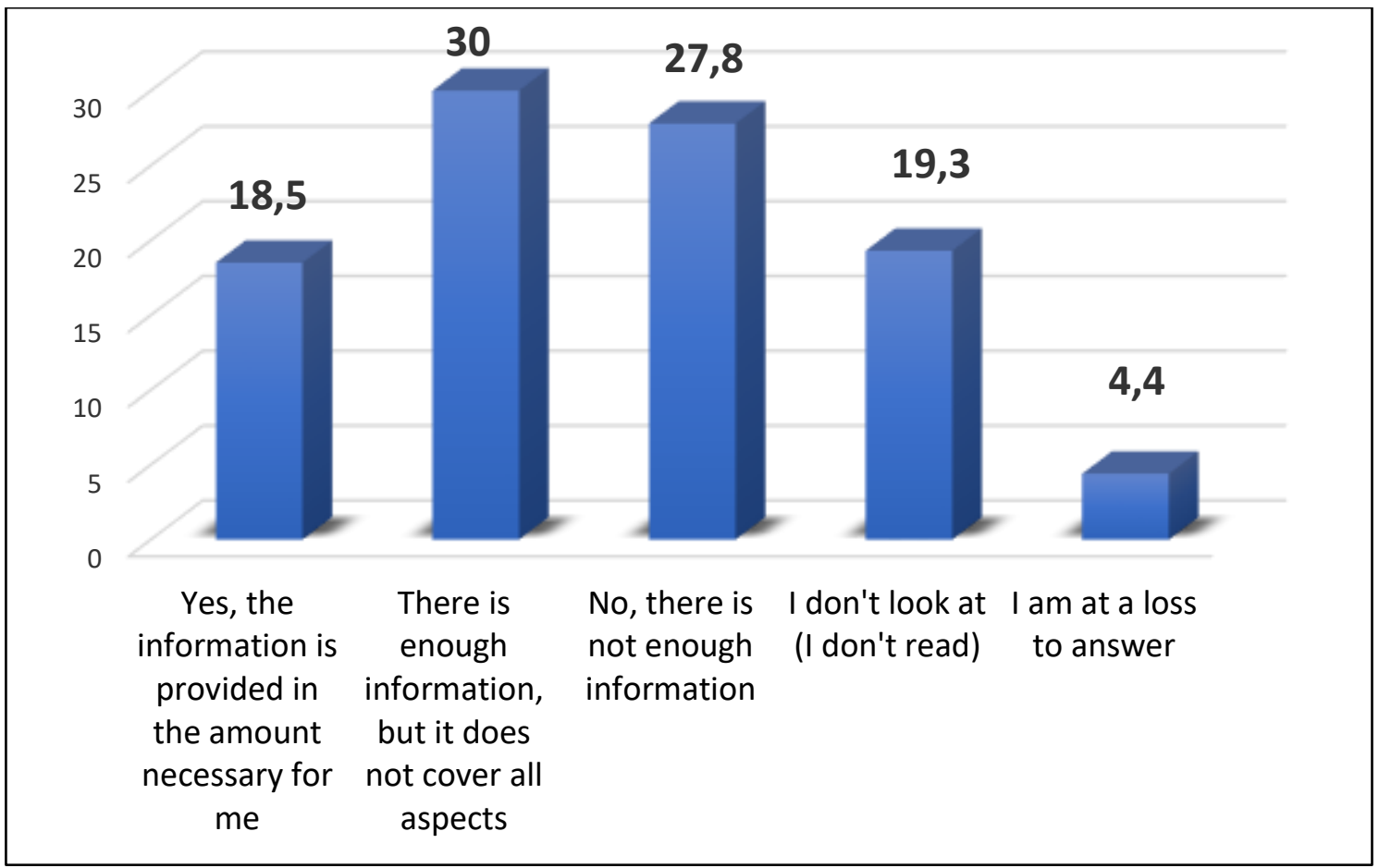

Fig.19. Is there enough information about anti-corruption policy in the local media (newspaper articles, TV, radio broadcasts)

25. $24.1 \%$ of experts put the Federal Security Service of the Russian Federation in first position among the bodies that most effectively counteract corruption in Russia followed by the Prosecutor's Office of the Russian Federation and other law enforcement agencies. At the bottom of the rating there are public authorities and local selfgovernment bodies, which are clearly underestimated by experts as subjects of combating corruption, despite the significant amount of work carried out by them. 


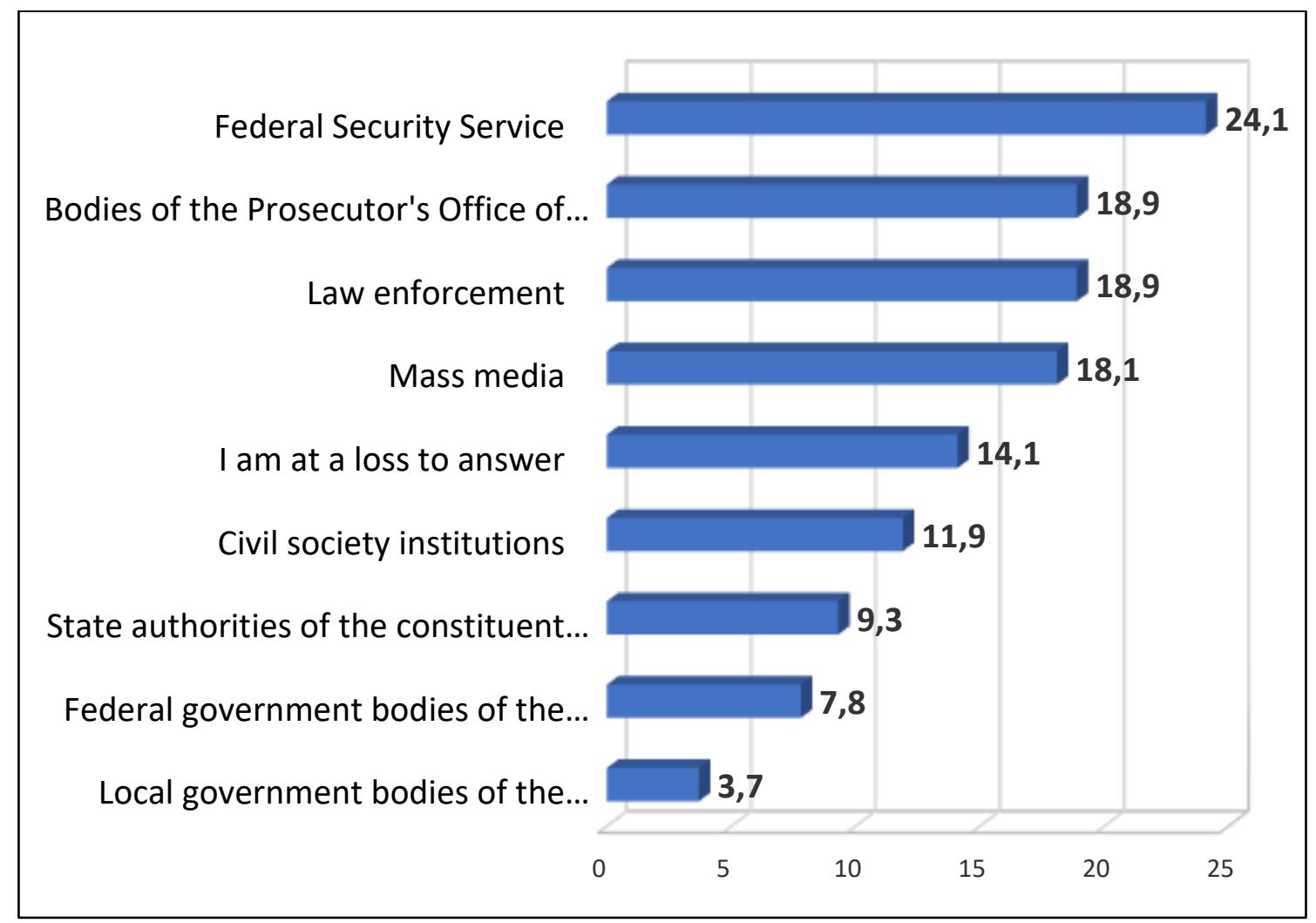

Fig. 20. What bodies are most effective in combating corruption in modern Russia?

26. As in the opinion polls of previous years, when answering the question about the arrests of officials who took bribes on an especially large scale, most experts consider these episodes not to be the result of a consistent anti-corruption policy of the state, but as "demonstrative performances" to create the appearance of fighting corruption. A little more than $20 \%$ of experts believe that those officials who did not deduct a percentage to their higher management have been detained. And only a quarter of experts think that "resonant" detentions are related to a systemic fight against corruption. (Fig.21) 


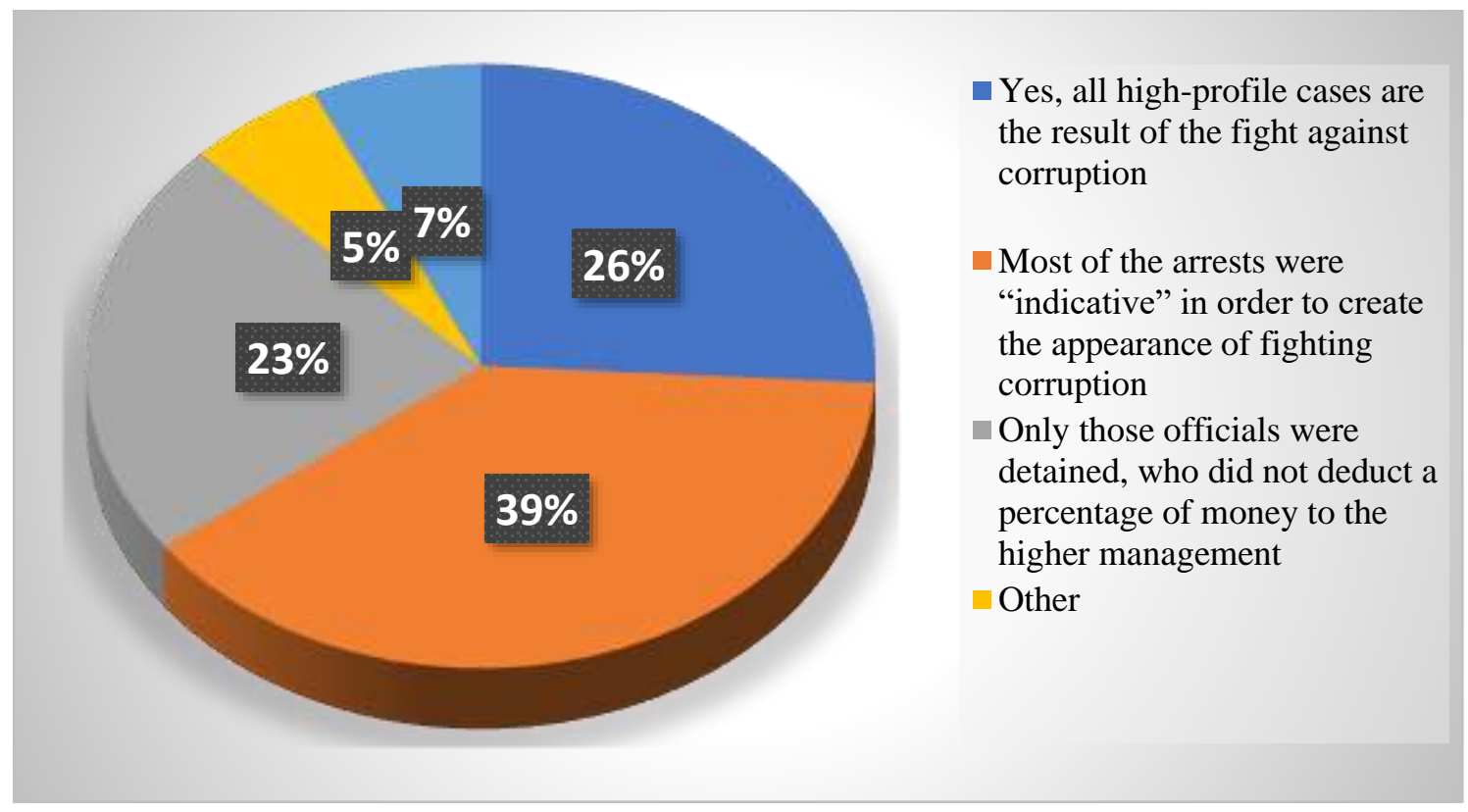

Fig. 21. Do the arrests of officials who took bribes on an especially large scale have a consequence in the form of the consistent anti-corruption policy of the state?

It should be noted that

27. Most experts believe that the punishment for corruption crimes should be made stricter than that specified in the RF Criminal Code. According to the experts, the second position was occupied by the answer that the punishment specified in the Criminal Code is fully consistent with the nature of the act. Every 5th expert believes that the punishment for accepting a bribe is excessively strict and unfair. compared to a similar question in the 2018 study,( Problems of combating corruption in the state and municipal services and ways to solve them in modern Russia. Materials of the participants of the Round Table with international participation, Rostov-onDon, 2018). the number of experts voting in favour of tougher punishment is decreased, and the number of experts who found it difficult to answer quadrupled. (Fig.22) 


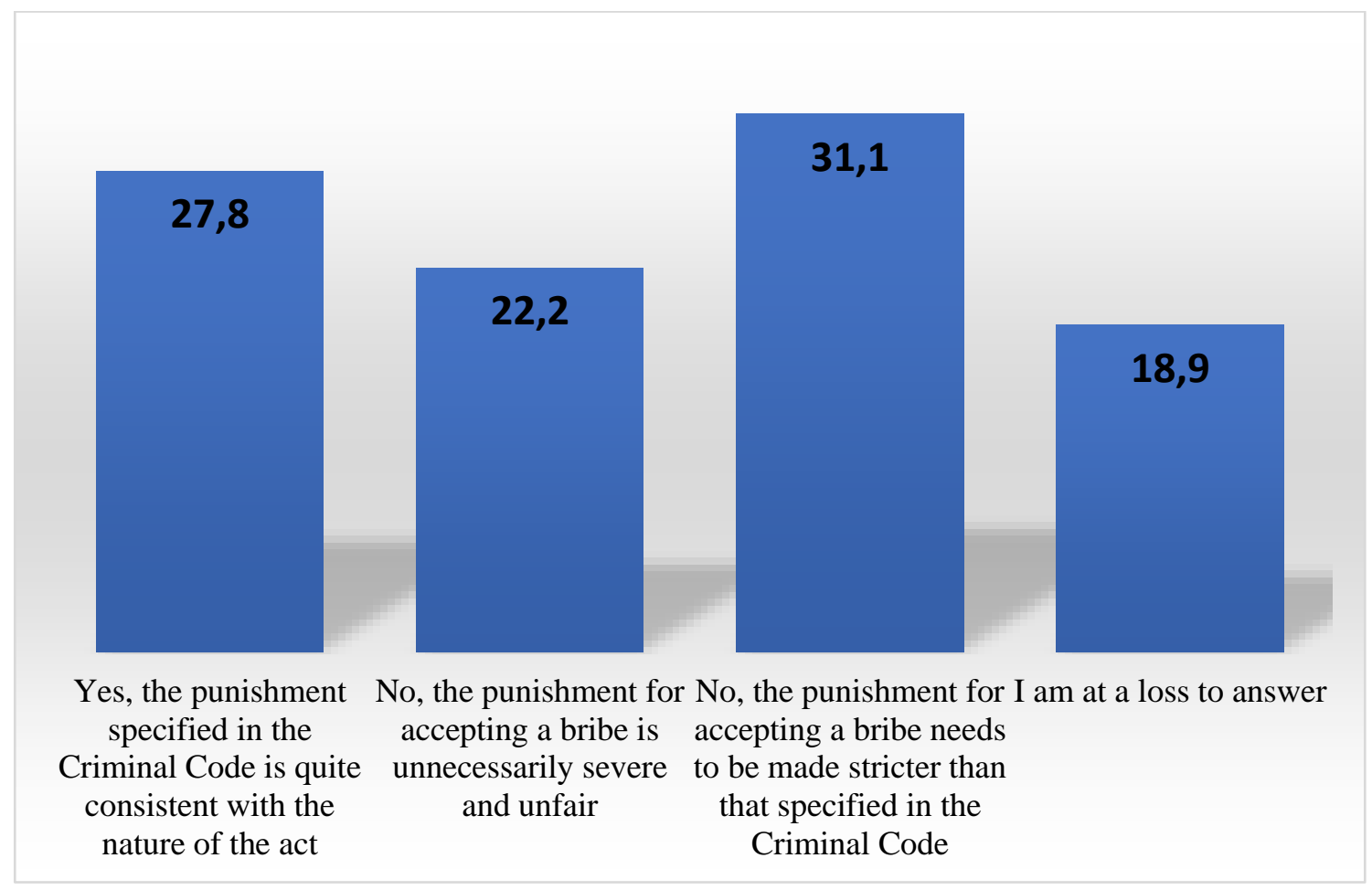

Fig. 22. Is the punishment for accepting a bribe specified in the legislation of the Russian Federation sufficient and fair for such an act?

28. Assessing measures that can lead to a decrease in the level of corruption in Russian society, the experts ranked the first five positions in the following sequence:

1) Establish a lifelong ban on civil service for officials convicted of corruption crimes;

2) Increase the efficiency of law enforcement agencies in the fight against corrupted officials by expanding the possibilities for conducting operationalsearch activities and introduce the practice of "provoking a bribe";
3) Strictly control the distribution and expenditure of budget funds;

4) To increase the legal literacy of the population in terms of the anticorruption component;

5) Introduce the rule of confiscation not only with regard to the property of persons convicted of a corruption offense, but also of their immediate family.

It is not difficult to note the propensity of experts to the repressive aspect of solving the problem, which 
seems to be a simpler and faster way than

the educational aspect. (Table 3 )

Table 3. What measures can lead to a decrease in the level of corruption in Russian society?

\begin{tabular}{|c|c|}
\hline Establish a lifelong ban on civil service for officials convicted of corruption offenses. & 29,3 \\
\hline $\begin{array}{l}\text { To increase the effectiveness of the activities of law enforcement agencies in the fight against } \\
\text { corruption expanding the possibilities for conducting operational-search activities and } \\
\text { introduce the practice of "provoking a bribe". }\end{array}$ & 28,1 \\
\hline Strictly control the distribution and expenditure of budget funds. & 27,4 \\
\hline To increase the legal literacy of the population in terms of the anti-corruption component. & 23,3 \\
\hline $\begin{array}{l}\text { Introduce the rule of confiscation not only with regard to the property of persons convicted } \\
\text { of a corruption offense, but also of their immediate family. }\end{array}$ & 22,2 \\
\hline $\begin{array}{l}\text { Track the property status of officials, and compliance of their expenses with officially } \\
\text { declared income. }\end{array}$ & 21,1 \\
\hline $\begin{array}{l}\text { Deprive persons convicted of corruption offenses from pension supplements as civil } \\
\text { servants. }\end{array}$ & 21,1 \\
\hline Tighten anti-corruption legislation and dramatically increase prison sentences. & 17,8 \\
\hline $\begin{array}{l}\text { Ensure openness of decision-making by the authorities for placing orders, rendering services } \\
\text { for state needs. }\end{array}$ & 15,6 \\
\hline $\begin{array}{l}\text { Introduce more widely a system of independent examination of draft laws and laws for their } \\
\text { corruption risks. }\end{array}$ & 11,9 \\
\hline Increase the salaries of state and municipal employees. & 11,5 \\
\hline $\begin{array}{l}\text { Provide an accessible and simple mechanism for judicial appeal against decisions of an } \\
\text { official. }\end{array}$ & 10,7 \\
\hline
\end{tabular}

29. Most experts said that the punishment for accepting a bribe should be the same for all officials, regardless of their rank. This position is only $3 \%$ ahead of the opinion that higher-ranking officials should be punished for bribery more severely than ordinary employees. (Fig.23) 


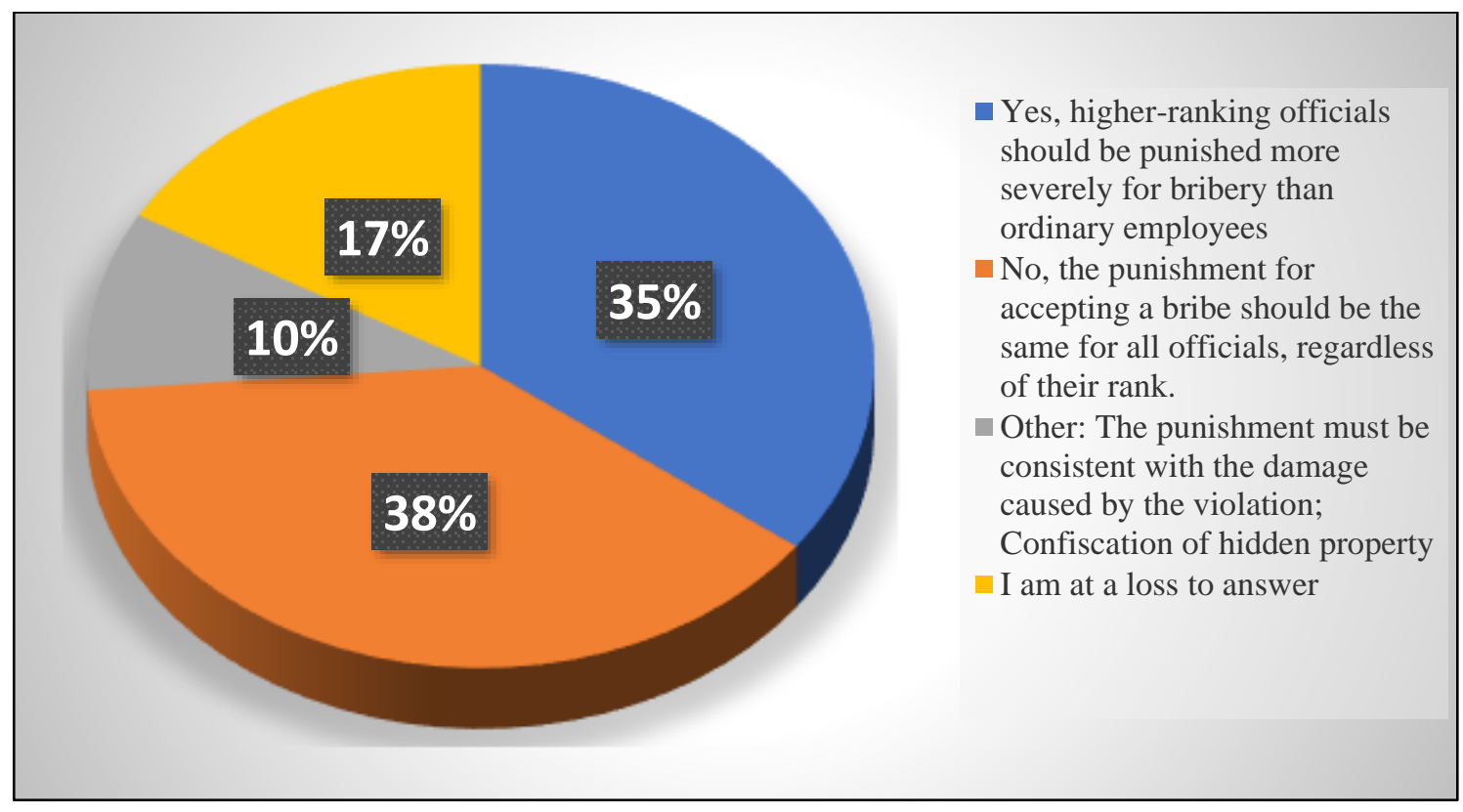

Fig. 23. Is it necessary in your opinion to determine the degree of punishment for bribery for officials depending on the level of their position?

30. The most significant answer options regarding the measures to be taken to reduce the level of corruption were ranked by experts as follows:

1) Strengthening anticorruption legislation;

2) Strict control over the distribution and spending of budgetary funds;
3) Ensuring openness of decision-making by the authorities on placing orders for the supply of goods and services for state (municipal) needs;

4) Improving the efficiency of law enforcement agencies in the fight against corruption.

5) Formation of an anticorruption worldview, increasing the legal literacy of the population. (Table 4)

Table 4. What should be done in your opinion to reduce the number of corrupted officials (bribe-takers)?

(\%)

\begin{tabular}{|l|l|}
\hline Strengthen anti-corruption legislation. & 28,9 \\
\hline Strictly control the distribution and expenditure of budget funds. & 24,4 \\
\hline
\end{tabular}




\begin{tabular}{|c|c|}
\hline $\begin{array}{l}\text { Ensure openness of decision-making by authorities on placing orders for the supply of goods } \\
\text { and services for state (municipal) needs. }\end{array}$ & 22,2 \\
\hline To form an anti-corruption worldview, to increase the legal literacy of the population. & 21,1 \\
\hline $\begin{array}{l}\text { To increase the effectiveness of the law enforcement agency activities in the fight against } \\
\text { corruption. }\end{array}$ & 21,1 \\
\hline Regulate the actions of officials when interacting with the population. & 20,0 \\
\hline $\begin{array}{l}\text { Start with ourselves and your loved ones: develop an unacceptable attitude towards } \\
\text { corruption. }\end{array}$ & 20,0 \\
\hline Provide more coverage of anti-corruption activities in the media. & 18,9 \\
\hline To increase the wages of state (municipal) employees and public sector employees. & 16,3 \\
\hline $\begin{array}{l}\text { Other: } \\
\text { - To increase the effectiveness of the activities of law enforcement officers and courts in the } \\
\text { fight against corruption in their ranks; } \\
\text { - It is necessary to revive in full the measures of moral and material incentives for labour. At } \\
\text { present, the awards concern a narrow circle of people; } \\
\text { - Introduce the death penalty for officials who take bribes; } \\
\text { - Inform the population about where the funds and property confiscated from bribe-takers } \\
\text { are directed. }\end{array}$ & 7,8 \\
\hline
\end{tabular}

31. A positive result of the sociological survey in comparison with similar studies of previous years is the willingness of $93 \%$ of experts to take personal part in anti-corruption activities. Every 5th expert is already involved in such work and considers it their civic duty. (Figs.24-25) 
Yes, I am ready to take part in anti-corruption actions aimed at improving legal literacy.

Yes, I am ready to address corruption facts (GIS

"People's Control", mass media, other Internet resources that provide an opportunity to involve such facts in a broad public discussion)

Yes, I am ready to apply to law enforcement agencies / higher authorities on decisions and actions of state and municipal authorities and their officials on the facts of corruption

Yes, I am ready to work in organizations that are purposefully engaged in the fight against corruption (non-profit organizations, human rights foundations, research centres, Internet projects, etc.)

I am already taking part, I consider it my civic duty

No, not ready

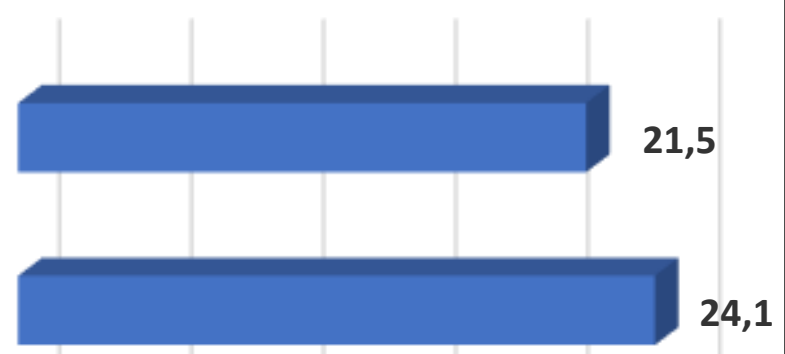

5

10

15

20

Fig. 24. Are you ready to take part in anti-corruption activities? 


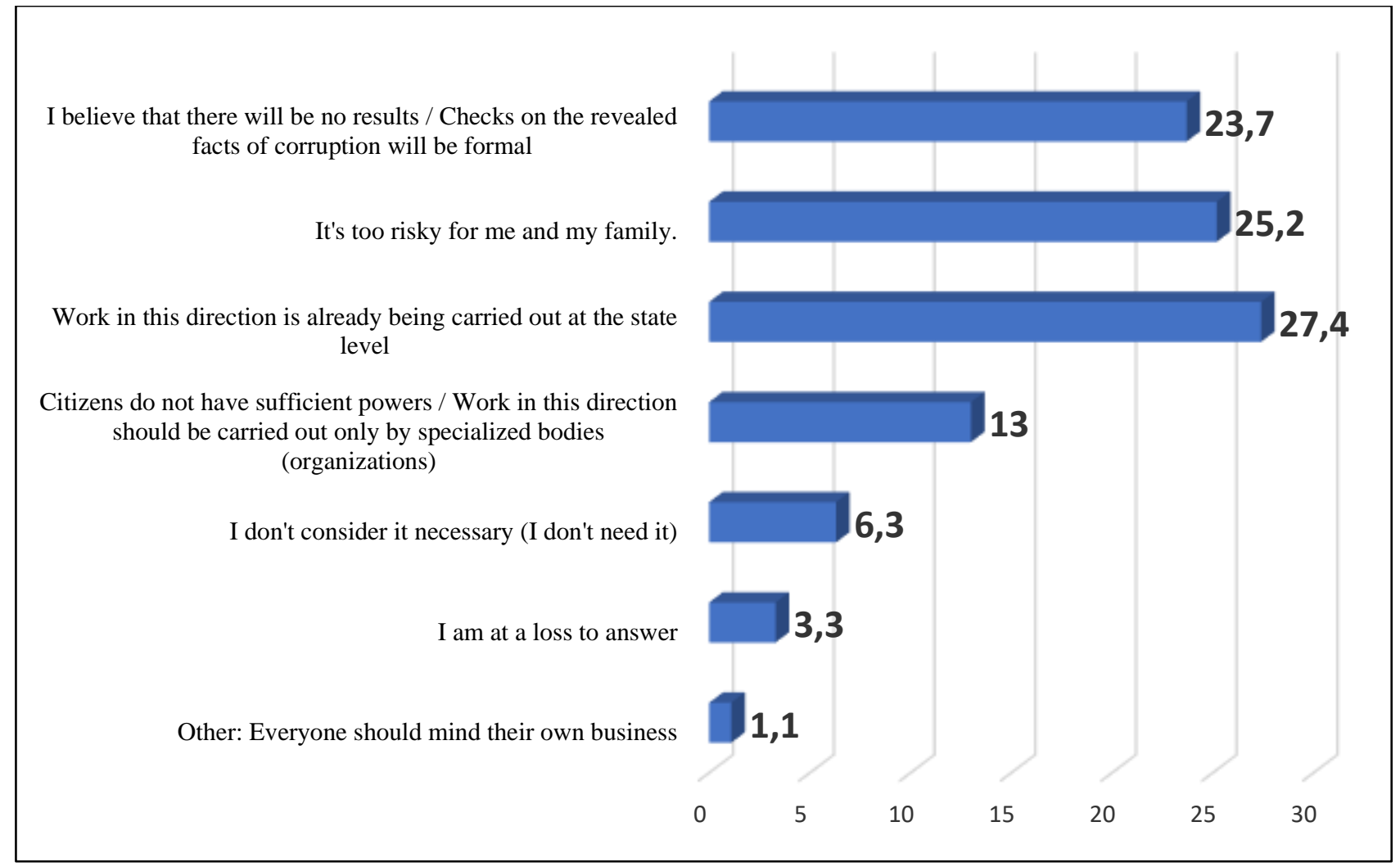

Fig. 25. If not, why?

32. Taking into account the above, it can be stated that the anticorruption policy remains unbalanced and does not inspire confidence, and, consequently, support from part of the population.

At the same time, the widespread opinion that corruption can be defeated through dictatorship and repression (the experience of China and other foreign countries) does not justify itself in practice. It is impossible to solve this problem only by means of legal suppression, since "susceptibility to corruption is part of human nature ... and if a cult of wealth has developed in society, then this only stimulates corruption”.( Bazhanov, 2013)

\section{CONCLUSIONS}

The need to improve the efficiency of combating corruption presupposes an increase in the influence of ethical and moral norms on the observance of prohibitions, restrictions, and requirements established in order to counter corruption, as well as the 
development of additional mechanisms and tools for preventing corruption manifestations. Moreover, it is clearly not enough to legalize the norms of anticorruption behaviour, through which law enforcement activities in this area could provide real results. Anti-corruption norms require not only legalization, but also legitimation, that is, recognition and support by citizens and society of this work as a whole. Only a combination of these two components can ensure an increase in the effectiveness of the prevention of corruption offenses in the Russian Federation.

It seems that the time has come to study and assess the effectiveness of legal regulation concerning the participation of civil society institutions in the work on the prevention of corruption. At the same time, attention should be paid to the development of measures to ensure proper guarantees for the participation of civil society institutions in the national anticorruption program.

It should be noted that the effectiveness of the regulatory impact of anti-corruption measures is constrained by the multiplicity and inconsistency of the normative legal acts regulating the scope of anti-corruption activities. In a number of cases, the relevant legislative regulation is either not supplemented by the regulatory framework of the subordinate level, or does not provide for an appropriate mechanism for the practical implementation of legislative norms aimed at combating corruption.

Anti-corruption legislative initiatives of political parties and social movements represented in the State Duma can be assessed as inappropriate to the level of threats. Many of them demonstrate a belated reaction to trends in the field of corruption, are abstract and declarative in nature, and are taken in isolation from the actual problems of the fight against corruption, and the real expectations and demands of society.

Legislative and law enforcement activities in the field of combating corruption systematically demonstrate not resistance, but a compromise, which negatively affects the authority of state bodies responsible for solving problems in the field of combating corruption, provokes legal nihilism among some citizens, disbelief in the goals and objectives declared by the anti-corruption policy. 


\section{References}

Anti-corruption results of [Electronic resource]. Access mode: https://anticor.hse.ru/main/news_page/a ntikorruptsionnye_itogi_2019_goda.

2019.

Bazhanov E.P., Bazhanova N.E. Dialogue and clash of civilizations. Moscow: Ves mir, P. 246. 2013.

Berthold Brecht. [Electronic source]. Access mode: https://www.litprichal.ru/work/318155/ Primakov E.M. "Thinking out loud". M $\therefore$ Rossiyskaya Gazeta, Pp. 94. 2011.

Problems of combating corruption in the state and municipal services and ways to solve them in modern Russia. Materials of the participants of the Round Table with international participation, Rostovon-Don, P. 482. 2018.
Resolution of the Plenum of the Supreme Court in the Russian Federation dated December 24, 2019 N 59 "On amendments to the decisions of the Plenum of the Supreme Court in the Russian Federation dated July 9, 2013 N 24 "On judicial practice in cases of bribery and other corruption crimes" and dated October 16, N 19 "On judicial practice in cases of abuse of office and abuse of office".2009

The number of identified bribes in Russia in increased by $10 \%$. [Electronic source].

Access mode:https://tass.ru/proisshestviya/7622 875. 2019

The Russian IC has analyzed the practice of investigating corruption crimes. [Electronic source]. Access mode: https://sledcom.ru/news/item/1417917/? print $=1$ 